University of Louisville

ThinkIR: The University of Louisville's Institutional Repository

Electronic Theses and Dissertations

$12-2019$

\title{
"I have prayed and prayed: I have labored and labored": ethnic catholicism in Daviess country Kentucky, 1850-1900.
}

\author{
Edward A. Wilson III \\ University of Louisville
}

Follow this and additional works at: https://ir.library.louisville.edu/etd

Part of the History Commons

\section{Recommended Citation}

Wilson, Edward A. III, "'I have prayed and prayed: I have labored and labored": ethnic catholicism in Daviess country Kentucky, 1850-1900." (2019). Electronic Theses and Dissertations. Paper 3401.

https://doi.org/10.18297/etd/3401

This Master's Thesis is brought to you for free and open access by ThinkIR: The University of Louisville's Institutional Repository. It has been accepted for inclusion in Electronic Theses and Dissertations by an authorized administrator of ThinkIR: The University of Louisville's Institutional Repository. This title appears here courtesy of the author, who has retained all other copyrights. For more information, please contact thinkir@louisville.edu. 
"I HAVE PRAYED AND PRAYED; I HAVE LABORED AND

LABORED": ETHNIC CATHOLICISM IN DAVIESS COUNTY

KENTUCKY, 1850-1900

\author{
By \\ Edward A. Wilson III \\ B.A., Eastern Kentucky University, Richmond
A Thesis Submitted to the Faculty of the College of Arts and Sciences of the University of Louisville for the Degree of \\ in Partial Fulfillment of the Requirements
}

Master of Arts in History

Department of History University of Louisville Louisville, Kentucky

December 2019 

"I HAVE PRAYED AND PRAYED; I HAVE LABORED AND LABORED": ETHNIC CATHOLICISM IN DAVIESS COUNTY KENTUCKY, 1850-1900

By

Edward Allen Wilson III

B.A. Eastern Kentucky University, 2014

Thesis Approved on

November 25, 2019

By the following Thesis Committee:

Dr. Glenn A. Crothers

Dr. Daniel Krebs

Dr. Amy Clukey 


\section{DEDICATION}

This thesis is dedicated to

Holy Mother Church

Virgin Mother Mary

and beloved mother Lea Ann 


\section{ACKNOWLEDGMENTS}

I would like to thank my adviser, Dr. A. Glenn Crothers, for his guidance and patience, despite my insufferable tendency to overly romanticize history. I would also like to thank the other committee members, Dr. Daniel Krebs and Dr. Amy Clukey, for their comments, assistance and willingness to struggle through my defense with such heavy demands on their time. I would also like to thank the Owensboro Museum of Science and History, as well as the Diocese of Owensboro, and Mount Saint Joseph for allowing me access to their archived materials. 


\title{
ABSTRACT \\ “'I HAVE PRAYED AND PRAYED; I HAVE LABORED AND LABORED': ETHNIC CATHOLICISM IN DAVIESS COUNTY, KENTUCKY 1850-1900”,
}

\author{
Edward Wilson
}

November 25, 2019

This thesis examines the development of the German and Irish Catholic communities of Daviess County, Kentucky. The primary focus of the work is the church building process and the separation of Catholic ethnic communities. Although they shared the same faith, American Catholics were divided by nationalism and ethnic hostility. Already isolated in the United States, immigrant Catholics formed cultural communities that adapted their foreign identity to their new surroundings.

Scholars often analyze Catholics in the United States during this period as a unified group, but this approach is flawed. Catholics developed hostilities against members of their own faith along ethnic lines. This study investigates how these divergent relationships affected the development of Catholicism in western Kentucky as well as in the United States. In-group hostilities in addition to the malice of native-born Protestants intensified the immigrants' attachment to their foreign identity generations after their forebears arrived in the U.S. 
TABLE OF CONTENTS

PAGE

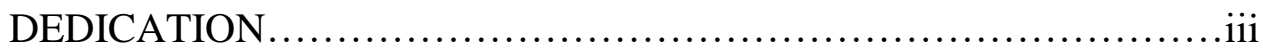

ACKNOWLEDGMENTS ......................................... iv

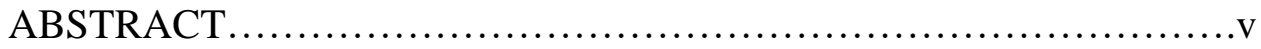

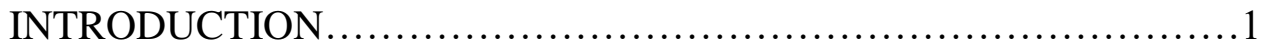

CHAPTER ONE: GERMANS IN OWENSBORO ......................9

CHAPTER TWO: "WHISKEY PEOPLE AND STABLE HANDS........30

CHAPTER THREE: THIS MOTHER OF HARLETS ...................50

CONCLUSION.................................................. 71

REFERENCES............................................... 75

CURRICULUM VITAE ............................................ 85 


\section{INTRODUCTION}

Two simultaneous events reveal the state of the American Union in 1884-1885. In Our Country, the champion of the Social Gospel Movement, the Reverend Josiah Strong, penned a warning to his fellow Protestants, arguing that "a mighty emergency is upon us. Our country's future and much of the world's future depend on the way in which Christian men meet the crisis." ${ }^{\text {S }}$ Strong spoke fearfully of the growing size and power of the Catholic Church in the United States. Meanwhile, the Third Plenary Council of the American Catholic Church gathered in Baltimore, the last of a series of meetings that sought to restructure the growing institution. Strong viewed the assembly of the American Catholic hierarchy as an invading force that sought the nation's downfall. He believed that God would thwart the plans of Catholics leaders, stop the influx of immigrants who supported the church, and stifle their dangerous beliefs. ${ }^{2}$ In contrast, the Catholic hierarchy viewed the plenary as a celebration of the church's progress in the United States.

America has experienced frequent waves of anti-foreign and anti-Catholic sentiment. In the colonial era, some colonists faced persecution and exile because their

\footnotetext{
${ }^{1}$ Josiah Strong, Our Country: Our Possible Future and Our Present Crisis (New York: Baker and Taylor, 1885), 217. Quote in thesis title is taken from Frank Kamuf in Gerald M. Wilkerson, That All May Be One: A History of Sts. Joseph and Paul Parish on Centenary Celebration of Saint Paul's Church, 1887-1987 (Utica, KY: McDowell Publishing, 1987), 79.

${ }^{2}$ Ibid.
} 
faith or ethnicity differed from the Protestant majority. ${ }^{3}$ This recurring feature of American society has shaped the country's development and the experience of many immigrant groups. Scholars have investigated the sources and consequences of the nation's hostility toward foreign newcomers. Fueled by a sense of ethnic and cultural supremacy and anti-Catholicism, scholars argue, nativism proved a popular idea in nineteenth-century America. However, studies of nativism have most often focused on large cities such as Boston, Milwaukee, St. Louis, and New York, reflecting their influence and the rich source material available to analyze them. ${ }^{4}$ But such studies offer an incomplete view of the larger immigrant experience. As historian John A. Hawgood argued, scholars cannot fully understand the immigrant experience without considering the rural perspective. ${ }^{5}$ Consequently, this study focuses on the town of Owensboro in Daviess County, Kentucky. A developing southern town in the mid to late nineteenth century, Owensboro offers a unique case study of the Catholic immigrant experience.

Some of the earliest works in the field of immigration history continue to shape scholarship. Oscar Handlin's The Uprooted (1952) and John Bodnar's The Transplanted (1985) present two differing understandings of American immigration that have divided scholars into two basic interpretive camps. Those who follow Handlin view the

\footnotetext{
${ }^{3}$ Peter Schrag, Not Fit for Our Society: Nativism and Immigration (Berkley: University of California Press, 2010), 1.

${ }^{4}$ For Boston, see Oscar Handlin, Boston's Immigrants, 1790-1880: A Study of Acculturation (1941; Cambridge, MA: The Belknap Press of Harvard University Press, 1991). For Milwaukee, see Kathleen Neils Conzen, Immigrant Milwaukee, 1836-1860: Accommodation and Community in a Frontier City (Cambridge, MA: Harvard University Press, 1976). For St. Louis, see Luke Ritter, "Sunday Regulation and the Formation of German American Identity," Missouri Historical Review 107 (October 2012): 23-40. ${ }^{5}$ John A. Hawgood, The Tragedy of the German American: The Germans in the United States of America during the Nineteenth Century — and After (New York: G. P. Putnam's Sons, 1940), 22.
} 
immigrant as an isolated victim, cut off from American life because of their foreignness and the bigoted attitudes of the broader society. ${ }^{6}$ Writing thirty years later, Bodnar responded to Handlin's study by describing immigrants as autonomous individuals, joined by shared origins, who pursued economic and social goals they could not attain in their homelands. In Bodnar's telling, family networks and group cohesion provided the groundwork that enabled immigrant communities to prosper. ${ }^{7}$ As a result of Handlin and Bodnar's studies, scholars continue to see the immigrant experience as rife with individual suffering and isolation and gradual communal success. In fact, both interpretations remain useful. Each new ethnic group that entered the United States faced prejudice, resentment, and persecution. Several studies have examined the roots and nature of this anti-immigrant persuasion, known as nativism, including John Higham's Strangers in the Land and Mathew Frye Jacobson's Whiteness of a Different Color. ${ }^{8}$ Both works investigate American nativism in the late nineteenth and early twentieth centuries. Higham chronicles the history of nativist bigotry and persecution in the United States, while Jacobson examines the creation of postbellum America's white racial hierarchy.

In response to persecution and in a search for familiar surroundings and security, immigrants soon formed ethnic communities. Over time, these discrete ethnic communities experienced a process of acculturation into American society, though the

\footnotetext{
${ }^{6}$ Oscar Handlin, The Uprooted: The Epic Story of the Great Migrations that Made the American People (Boston: Little, Brown, 1952). ${ }^{7}$ John Bodnar, The Transplanted: A History of Immigrants in Urban America (Bloomington: University of Indiana Press, 1985).

${ }^{8}$ John Higham, Strangers in the Land: Patterns of American Nativism, 1860-1925 (New Brunswick, NJ: Rutgers University Press, 1988); Matthew Frye Jacobson, Whiteness of a Different Color: European Immigrants and the Alchemy of Race (Cambridge, MA: Harvard University Press, 1998).
} 
length of this process varied significantly. Certain ethnic groups acculturated more readily than others. Several factors accelerated or impeded this process, including group size and isolation. ${ }^{9}$ If an immigrant group was large or secluded enough, it could take a generation or more for acculturation to take place. Such communities had limited access to the broader American society and had little impetus to acculturate. Indeed, some immigrants believed they could establish separate cultural communities, such as a "New Germany," on American soil. ${ }^{10}$ Such ethnic enclaves did not develop in Owensboro or Daviess County, where immigrants interacted regularly with the broader community. Still, when immigrant communities in Owensboro developed their own educational, religious, and cultural institutions the process of acculturation sometimes faltered or slowed, revealing the complexities of the process.

Another factor that influenced acculturation was ethnicity. In Owensboro, for example, Germans took longer to acculturate than the Irish. Several reasons account for Germans' slower acculturation, including the preservation of their language and customs, isolation, and Catholic faith. The Irish faced comparable problems, but they did not share the language barrier nor did they actively resist acculturation. As historian David T. Gleeson notes in The Irish in the South, 1815-1877, the Irish proved more malleable than other ethnic groups, particularly in the South, in large part because the Irish actively pursued incorporation into American society. ${ }^{11}$ In contrast, Germans found it more

\footnotetext{
${ }^{9}$ Elliot R. Barkan, Rudolph J. Vecoli, Richard D. Alba, Olivier Zunz, "Race, Religion, and Nationality in American Society: A Model of Ethnicity, from Contact to Assimilation," Journal of American Ethnic History 14 (Winter 1995): 38-101.

${ }^{10}$ Gerald M. Wilkerson, That All May Be One, 55.

${ }^{11}$ David T. Gleeson, The Irish in the South, 1815-1877 (Chapel Hill: University of North Carolina Press, 2001), 140. See also Hawgood, Tragedy of the German American, 32.
} 
difficult to reconcile their German identity with American practices. Their determination to preserve their customs and language slowed their rate of acculturation. ${ }^{12}$

Catholicism in Kentucky originated out of the migration of Maryland's Catholic population in the late eighteenth century. Catholics left Maryland in large numbers in these years because of declining agricultural output and economic depression rather than religious persecution. ${ }^{13}$ However, the impoverished state of Maryland's Catholics prior to the depression of the 1780s was a product in part of "religious and political discrimination." ${ }^{14}$ Catholics first settled in Kentucky in 1785, establishing the community of Pottinger's Creek in Nelson County. The following year, Catholics founded Hardin's Creek and they continued establishing settlements, primarily in Nelson County, over the decade. ${ }^{15}$ These early Catholic migrants hoped that a priest would accompany them to Kentucky and they made founding a church a high priority. Living in close proximity, the settlers sought a centrally located church that was accessible to all. ${ }^{16}$ However, few priests served the United States in the era and their goal was unachievable.

As a result, Catholics in Kentucky had to wait years before priests arrived. The first priest to settle in Kentucky was Father M. Whelan, who served between 1787 and 1790. Six months later, Father William de Rohan arrived in Kentucky and helped erect

\footnotetext{
${ }^{12}$ Hawgood, Tragedy of the German American, 37.

13 Thomas W. Spalding, "The Maryland Catholic Diaspora," U.S. Catholic Historian 8 (Summer 1989): 163.

${ }^{14}$ Mary Ramona Mattingly, The Catholic Church on the Kentucky Frontier (1785-1812) (Washington D.C.: Catholic University of America, 1936), 1.

${ }^{15}$ Benedict Joseph Webb, The Centenary of Catholicity in Kentucky (Louisville: C. A. Rodgers, 1884), 366.

${ }^{16}$ Mattingly, Catholic Church on the Kentucky Frontier, 23.
} 
Holy Cross, the first Catholic church in the state. More priests soon arrived but the most notable was Father Steven Theodore Badin, who began his work in Kentucky in 1795. Born on July 17, 1768 in Orleans, France, Badin fled France while in seminary because of the French Revolution. Arriving in the United States in 1791, Badin tirelessly served Kentucky Catholics until 1819. In 1805, another outstanding figure in the history of Catholicism in Kentucky, Father Charles Nerinckx, arrived in the state. ${ }^{17}$ Born on October 2, 1761, in Herffelingen, Belgium, Nerinckx also suffered from persecution during the French Revolution. ${ }^{18}$ In 1797, French forces invaded Belgium and issued an order for Nerinckx's arrest after the priest continued to administer the sacraments and refused to swear "the blasphemous oath of undying hatred to royalty." ${ }^{19}$ Nerinckx went into hiding but continued to serve the faithful and opponents of the French Revolution in secret. ${ }^{20}$ Hearing the call to mission, Nerinckx decided to journey to America. He arrived in the United States in 1804 and accepted an appointment to serve in Kentucky. The labor of these two priests, refugees from their homelands, laid the groundwork for Catholicism in the state.

As settlement in Kentucky progressed, Catholics moved west, making an additional mission necessary. Father Elisha J. Durbin took responsibility for establishing

\footnotetext{
${ }^{17}$ Webb, Centenary of Catholicity in Kentucky, 26. See also, The Roman Catholic Diocese of Owensboro, Kentucky (Nashville, TN: Turner Publishing Company, 1994), 13.

${ }^{18}$ Camilles P. Maes, The Life of Rev Charles Nerinckx: With a Chapter on the Early Catholic Missions of Kentucky; Copious Notes on the Progress of Catholicity in the United States of America, from 1800 to 1825; an Account of the Establishment of the Society of Jesus in Missouri; and an Historical Sketch of the Sisterhood of Loretto in Kentucky, Missouri, New Mexico, etc. (Cincinnati: R. Clarke and Co, 1880), 1.

${ }^{19}$ Ibid., 16.

${ }^{20}$ Ibid., 16-25.
} 
this ministry. He became known as the patriarch-priest of Kentucky. In 1824, Durbin assumed the pastoral duty of all of western and southwestern Kentucky, an expansive area that ranged from the Ohio River in the north to Tennessee in the south and from Jefferson County in the east to the Mississippi River in the west. Durbin played a seminal role in fostering Catholicism in Daviess County and western Kentucky. He made frequent visits to Daviess County to serve the large population of Catholics settled in the Panther Creek area, a few miles southwest of Owensboro. ${ }^{21}$ Church records and oral testimony indicate that Durbin was a faithful shepherd of the early Catholic communities of the county, including the parishes of St. Lawrence, Saint Mary of the Woods, and St. Alphonsus. ${ }^{22}$ He worked tirelessly to nurture Catholic growth and serve its scattered population. The work of these early leaders and the congregations they served formed the foundation of Kentucky and Daviess County's Catholic Church.

Scholars usually study religious communities as singular entities, but ethnicity and culture fractured the cohesion of the Catholic community of Owensboro and Daviess County in the latter half of the nineteenth century. This study investigates the development of these ethnic communities and the role of the church in their growth. The late nineteenth century was a significant era for the Catholic Church in America. At the First Ecumenical Council of the Vatican (1869-1870), with the declaration of "Pastor aeternus," Pope Pious IX established the doctrine of papal infallibility. The decree solidified the idea of Catholicism as the one true religion, deeming it flawless, and

${ }^{21}$ Webb, Centenary of Catholicity, 366.

22 Sarah Patterson "The Catholic Church in Daviess County," in Daviess County Kentucky, 1815-2015: Celebrating Our Heritage (Evansville, IN: M.T. Publishing, 2015), 133. See also, Diocese of Owensboro, Kentucky, 147, 121. 
identifying its adherents as the hands of God's divine will on earth. ${ }^{23}$ However, Catholics in America remained ethnically divided. Thus, the Third Plenary Council of Baltimore declared in "Title viii, Of Zeal for Souls" that "Immigrants should be instructed by priests of their own language." ${ }^{24}$ Though the long-time practice of the American church, this decree made the policy official. The American Catholic Church thus remained divided by ethnicity and culture. Catholics also faced the contempt of the country's Protestant majority. The long history of conflict between Protestants and Catholics, along with the papal declaration establishing the pope as "the pastor and teacher of all Christians" 25 embittered and frightened Protestants, as did the influx of Catholic immigrants in the nineteenth century. In these circumstances the Catholic community of Daviess County developed. They confronted the local manifestations of the nativism and anti-Catholicism that abounded in the United States in the late nineteenth century while also beset by internal divisions resulting from ethnic differences within the Catholic community.

Under these tumultuous conditions the ethnic Catholic communities of Owensboro developed and ultimately prospered. Experiencing both the isolation described by Handlin and the ethnic cohesion identified by Higham, the German and Irish communities advanced. In spite of the hostilities of their new surroundings, both groups adapted and established Catholic institutions for themselves in the community.

23 "Pastor Aeternus" http://www.catholicplanet.org/councils/20-Pastor-Aeternus.htm (accessed May 19, 2018).

24 "Plenary Councils of Baltimore" http://www.newadvent.org/cathen/02235a.htm (accessed 5/19/2018). .

${ }^{25}$ Charles L. Sewrey, "Infallibility, the American Way, and Catholic Apologetics," Journal of Church and State 15 (Spring 1973): 292. 


\section{CHAPTER ONE:}

\section{GERMANS IN OWENSBORO:}

\section{COMMUNITY DEVELOPMENT AND THE SIGNIFICANCE OF CHURCH}

\section{BUILDING}

Germans in Owensboro in the mid to late-nineteenth century experienced the same tribulations as their counterparts elsewhere in America. Most were skilled tradesmenblacksmiths, tailors, shoemakers, bakers, and coopers - whose labor helped them sustain their lives in their new home. The 1850 census, for example, identified eighteen of the twenty-two working Germans as skilled laborers while the remaining four were employed as a hotel keeper, a clerk, and laborers. ${ }^{26}$ Nonetheless, the native-born population of the town found German customs and culture alien. Germans' attachment to their language and heritage intensified in the face of rising nationalism, and church politics. Many German Catholic newcomers believed American culture inferior to their own. They looked to the Catholic Church to ensure the "preservation and cultivation of German heritage" and as "the primary source of education for German children."27

Germans' tendency to remain within their own community served as a protective

${ }^{26}$ U.S. Census Bureau, 1850 Kentucky Census of Daviess, Edmondson, and Estill (Washington: National Archives Microfilm Publications, 1963).

${ }^{27}$ Kathleen Neils Conzen, "Immigrant Religion and the Public Sphere: The German Catholic Milieu in America" in German-American Immigration and Ethnicity in Comparative Perspective, ed. Wolfgang J. Helbich (Madison, WI: Max Kade Institute for German-American Studies, 2005), 98, 108-09. See also Reinhard R. Dorries, "German Immigrants and the Church," in German-American Immigration, 15. 
mechanism, but it also confirmed the suspicions of many native-born residents. Likewise, the Germans' Catholic faith contributed to their position as outsiders among the town's Protestant majority. But their faith community also offered little reprieve from nativism, because native-born Catholics viewed German culture as inferior. Such attitudes exacerbated the group's tendency to embrace reclusiveness and cultural autonomy. Despite their industriousness, then, the cultural isolation of Owensboro's German Catholic population separated them both from their fellow Catholics and the Protestant majority.

Scholars attribute the German presence in Daviess County to the work of Father Joseph Kundek, who ministered in southern Indiana in the 1830s. Kundek embodied what Catholic historian John Rothensteiner labeled "early pioneer priests." Rothensteiner argued that the men called to missionary work in the American West were not scholar saints or religious philosophers like St. Thomas Aquinas. Instead, the Church needed "men of strong nerves, as well as strong faith to uphold her rights and protect her interest ... unto the dawn of a better day." ${ }^{28}$ Men of action like Kundek also forged institutions in the expanding region. A Croatian Catholic, Kundek arrived in Jasper, Indiana, in 1838, attracting many Germanic families to southern Indiana. Historian Kathleen Neils Conzen notes the power of an established church in attracting immigrants to an area. In a foreign land, standardized religious worship became a source of stability and many immigrant settlements thus developed around Catholic churches. ${ }^{29} \mathrm{~A}$ tireless missionary, Kundek

${ }^{28}$ John Rothensteiner, "Paul de Saint Pierre: The First German-American Priest of the West," The Catholic Historical Review 5 (July-October 1919): 195.

${ }^{29}$ Conzen, Immigrant Milwaukee, 36. 
helped establish the towns of Fluda, Tell City, Mariah Hill, and St. Meinrad, ${ }^{30}$

envisioning the creation of a "New Germany" in the area. ${ }^{31}$ His impact on Owensboro occurred after his work in Indiana.

Local historian Lee Dew states that following the Civil War, Germans began to arrive in Owensboro with Kundek's encouragement. He argues that the rising German population of southern Indiana increased land prices, making it more difficult for new residents to purchase land. After the war, according to Dew, Kundek traveled to Daviess County, Kentucky, and returned to southern Indiana to spread the news that affordable land could be purchased south of the river. Germans, Dew argues, crossed the river, purchased land in the Panther Creek area, and began to prosper. ${ }^{32}$ But Dew's narrative is inaccurate because the roots of Owensboro's German community predated the Civil War and Kundek himself died in $1857 .{ }^{33}$ The 1850 census of Daviess County reveals that Germans already had a substantial presence in the area, with sixty-two of Owensboro's 794 white residents German born or the children of German parents. The number might have been higher but the census does not identify first-generation Americans of German

${ }^{30}$ History of Warrick, Spencer, and Perry Counties, Indiana: From the Earliest Time to the Present; Together with Interesting Biographical Sketches Reminisces, Notes, Etc. (Chicago: Goodspeed Brothers, 1885), 434-35.

${ }^{31}$ Hawgood, Tragedy of the German American, 96. Hawgood defined a "New Germany" as "in essentials the desire to transplant German civilization and life to a region where it could develop unhampered by the restrictions (whether political, social or economic) then obtaining in Germany and in Europe generally, and in their new environment to keep the German settlers racially and culturally distinct, geographically isolated, and as far as possible politically and economically independent of outside or alien influence or interference."

${ }^{32}$ Lee A. Dew, "Our People: A Burgoo Pot of Cultures," in Daviess County, Kentucky, 19-20.

33 “Kundek Corner: Ferdinand Distinguished Citizens, Father Joseph Kundek," Ferdinand Historical Society, http://www.ferdinandhistory.org/index.php/kundek-corner/fr-josephkundek (accessed September 3, 2018). 
descent who migrated to the area. ${ }^{34}$ If a child born in Indiana to German parents subsequently migrated to the area, their ancestry went unrecorded.

Germans migrated to Daviess County because of the region's forests, proximity to the Ohio River, and the presence of Owensboro. According to historian John Hawgood, Germans followed settlement patterns that made Owensboro and Daviess County a good fit. Hawgood argued that Germans did not typically settle in frontier areas. Instead, they settled in towns and enjoyed the benefit of urban amenities. By midcentury, Owensboro was well-established, with a population of nearly eight hundred. Hawgood also noted Germans' tendency to move from "forest to forest," 35 both before and after the Civil War. ${ }^{36}$ The success of the initial German settlers in Daviess County encouraged more Germans from surrounding communities and Europe to move to the area in a process scholars have labeled "chain migration." 37

The 1850 census also reveals the insular habits of the German community. Germans married within their ethnic group and continued the use of the German language, a widespread practice among nineteenth century immigrants. The German clergy bolstered this tendency, encouraging the preservation of German and resistance to English as a way to keep the German population within the church. ${ }^{38}$ Immigration historians label the habit of secluding the community "clannishness" and a "stockade

${ }^{34} 1850$ Kentucky Census.

${ }^{35}$ Hawgood, The Tragedy of the German American, 25-29.

${ }^{36}$ Diocese of Owensboro, 145.

${ }^{37}$ LaVern J. Rippley, "The Ethnic Frontier: Rural Germans and the Settlement of America," in Immigrant America: European Ethnicity in the United States, ed. Timothy Walsh (New York: Routledge, 1994), 196-216.

${ }^{38}$ Conzen, "German Catholic Milieu," 101. 
mentality. ${ }^{{ }^{39}}$ Other scholars recognize how external forces hindered the process of German acculturation. Catholic historian Thomas Stefaniuk argues that Catholic German Americans "were different from most other Americans because of their German ethnicity and language and Catholic faith, different from other German-Americans because of their religion (the majority of German-Americans were Lutheran), and different from other 'American' Catholics because of their German ethnicity." ${ }^{40}$ Conzen concurs, noting that throughout the United States German Catholics differed from English-speaking Catholics as much as they did from non-Catholic Americans. ${ }^{41}$ Thus, their seclusion, though partially self-imposed, also resulted from pressures outside the German Catholic community.

Before the arrival of the Germans, Catholics had limited influence in Daviess County. Catholics celebrated mass in the area as early as 1821 , with the parishioners served by Father Elisha J. Durbin of Union County, Kentucky. In 1831, local Catholics erected a log structure, and the church, known as St. Lawrence, served Daviess County and the surrounding area. The church stood as the only physical outpost of Catholicism in the region for nearly a decade. Local parishioners hoped the construction of St. Lawrence would attract more Catholic settlers, but the church was built on poor land and attracted few farmers to the surrounding area. ${ }^{42}$ The parish erected a brick edifice in 1838 , but careless construction forced its reconstruction in $1870 .{ }^{43}$ In 1845, Richard W. Barrett

\footnotetext{
${ }^{39}$ Rippley, "The Ethnic Frontier," 205.

40 Thomas Stefaniuk, "Joseph Jessing, German-American Catholics, and National MythMaking in Late Nineteenth-Century America," American Catholic Studies 126 (Spring 2015): 3-4.

${ }^{41}$ Conzen, "German Catholic Milieu," 96.

${ }^{42}$ Webb, Centenary of Catholicity in Kentucky, 427.

${ }^{43}$ Diocese of Owensboro, 147.
} 
donated a plot of land lying a short distance from Whitesville, and a second Catholic church, St. Mary of the Woods, was erected and began administering sacraments in Daviess County. ${ }^{44}$ A third community, which would become St. Alphonsus, dated to 1825. Like the early communities in St. Lawrence and St. Mary of the Woods, St. Alphonsus was visited by Father Durbin and he administered the sacraments in the absence of a church. In 1854, John Rodman donated a plot of land on which a log church, St. Alphonsus, was built. ${ }^{45}$ But Owensboro remained without a Catholic church until 1838, when planning began for the construction of St. Stephen.

On June 15, 1838, Father Martin J. Spalding, the future bishop of Louisville, stood on the steps of the Owensboro courthouse and argued that the number of Catholics in the town had grown large enough to make a new church necessary. At the time, thirtythree Catholic families lived in the city. ${ }^{46}$ In response, local Catholics erected St. Stephen at Second and Mulberry Streets and dedicated it on August 21, 1842. It remained the only Catholic church in Owensboro for nearly thirty years and it served both native-born and immigrant congregants. However, the German and Irish members of St. Stephen could not worship alongside native-born congregants. ${ }^{47}$ Though a Belgian immigrant priest presided over the church, native-born parish leaders regulated access to the church and forced Germans and other immigrants to sit in the back pews. ${ }^{48}$ Germans and other immigrants recognized their second-class status within the church. One young woman, Mary Tennes Oberst, recalled that "all the pews had doors, and some had locks on them;

\footnotetext{
${ }^{44}$ Patterson, "Catholic Church in Daviess County," 133.

${ }^{45}$ Diocese of Owensboro, 121.

${ }^{46}$ Ibid.

${ }^{47}$ Diocese of Owensboro, 146.

${ }^{48}$ Wilkerson, That All May Be One, 60.
} 
the doors were locked to keep the Germans out." 49

In response, aggravated Germans sought to establish their own church. The arrival of Father Paul Joseph Volk in 1870 provided the impetus for the creation of a new German church. Born and raised in Germany, Volk was a devout and pious Catholic. His father died while he was young, and his mother instilled in him a reverence for the Catholic Church. Devotion to the faith led Volk to the seminary and missionary work in the United States. Volk knew the hardships he would face in America where an antiCatholic and nativist population made church building difficult. Before departing for America, Volk also struggled to learn the English language. He spent long hours in the garden of his college, translation book in hand, mumbling English language lessons. Though his fellow students often jeered him, he persevered and became fluent in English. ${ }^{50}$

Equally troublesome for the young priest, the years Volk spent in seminary were a tumultuous period in the history of the Catholic Church in Germany. The effort to unify Germany produced a clash between the Catholic Church and German nationalists. ${ }^{51}$ German Chancellor Otto von Bismarck, in an attempt to empower the state, enacted sanctions to limit the influence of the Catholic Church in Germany. His actions produced a struggle known as the "Kulturkampf," which prompted many Catholics to flee

\footnotetext{
${ }^{49}$ Mary Tennes Oberst, “Origin of St. Joseph’s Church, Owensboro, Kentucky,” 2, St. Joseph Collection, Mount St. Joseph Archives, Maple Mount, Kentucky.

${ }^{50}$ Norbert Russwurm, Rev. Paul Joseph Volk: A Pioneer Missionary in Two Continents (St. Bernard, AL: St. Bernard Abbey Book Shop, 1937), 3-4.

${ }^{51}$ Pontus Hiort, "Constructing Another Kind of German: Catholic Commemorations of German Unification in Baden, 1870-1876," The Catholic Historical Review 93 (January 2007): 19.
} 
Germany. ${ }^{52}$ According to political theorist Harold Joseph Laski, the ideologies of Catholicism and nationalism were "perhaps the two most fundamental facts of the nineteenth century," but they were also antithetical. ${ }^{53}$ In Germany, the presence of both of these forces resulted in a bitter power struggle. Though the Kulturkampf did not take place until two years after Volk left for America, Bismarck's preceding sanctions soured the relationship between the clergy and the state. The battle between the Catholic Church and the Prussian government came to a head during Volk's time in seminary, and likely accelerated his departure for the United States. ${ }^{54}$

In the summer of 1869 , Volk made the journey across the Atlantic Ocean and accepted a position as assistant to Father Francis X. Van Deutekom in Louisville. Volk likely felt welcome in the large town with a thriving German community. ${ }^{55}$ German singing groups, fraternal societies, festivals, and beer halls were staples of the city's cultural life ${ }^{56}$ But Volk remained a missionary at heart and Louisville did not become his final home. He felt called to spread the faith where it remained weak, and by 1869 Louisville's Catholic Church was well established. A year later Volk made his way to Daviess County.

The Owensboro in which Volk settled had changed markedly since 1850. By

\footnotetext{
${ }^{52}$ Dorries, "German Immigrants and the Church," in German-American Immigration, 3. ${ }^{53}$ Harold Joseph Laski, Studies in the Problem of Sovereignty (New Haven, CT: Yale University Press, 1917), 211-12.

${ }^{54}$ Douglas W. Hatfield, "Kulturkampf: The Relationship of Church and State and the Failure of German Political Reform," Journal of Church and State 23 (Autumn 1981): 471, 481-82.

${ }^{55}$ Dale T. Knobel, "To Be an American: Ethnicity, Fraternity, and the Improved Order of Red Men," Journal of American Ethnic History 4 (Fall 1984): 77.

${ }^{56}$ C. Robert Ullrich, Jane K. Keller, and Joseph R. Reinhart, "Germans," The Encyclopedia of Louisville, ed. John E. Kleber (Lexington: University of Kentucky Press, 2001), 338-39.
} 
1870 , the number of Germans living in the city had grown significantly, from sixty two to 432, a majority of whom came from the traditionally Catholic southern German communities of Baden and Bavaria. ${ }^{57}$ The 1870 census lists other German-speaking immigrants as coming from Hesse-Darmstadt, Prussia, Switzerland, Württemberg, Nassau, Hanover, Saxony, Mecklenburg, and Hamburg. The trend of Germans marrying within their own community also continued. Of the seventy-two marriages including a German, fifty seven—or nearly 80 percent—involved Germans marrying other Germans. These numbers illustrate the continued growth of German community in Owensboro and the persistence of their tendency to marry members of their own ethnic community. ${ }^{58}$

Volk succeeded Father Charles Eggermont, the pastor of St. Alphonsus. The early settlers of St. Alphonsus had received visits from pioneer priests, the earliest of which was Father Durbin who served the community from 1825-1831. Father John Wathen succeeded Durbin and served until 1837. In 1854, Father Walter Coombs, Wathen's successor, oversaw the construction of the first log church to serve the community. This church stood until 1868 when fire destroyed it. Thus, when Volk arrived to St. Alphonsus in 1870 , the young priest's first duty became rebuilding the church. Volk spent days laboriously helping with the construction of the new church. He attended the burning of the brick and personally assisted in erecting the building. When completed, the new building was eighty-four by forty-five feet in size ${ }^{59}$ But new challenges soon confronted the priest and his congregation. Shortly after Volk's arrival the church's school, built in

\footnotetext{
${ }^{57}$ U.S. Census Bureau, 1870 Kentucky Census, which lists Germans' birth location by province.

${ }_{58}^{58} 1870$ Kentucky Census.

${ }^{59}$ Diocese of Owensboro, 121.
} 
1863 by the Sisters of Loretto, burned to the ground five days after Christmas. The Sisters abandoned the school and the area soon became overgrown. ${ }^{60}$ Following the completion of St. Alphonsus, Volk turned his attention to the lot where the school once stood. He communicated with William George McCloskey, bishop of the Diocese of Louisville, and they concluded that a convent and school for young women would be of great service to the area. ${ }^{61}$

Volk's congregation at St. Alphonsus consisted largely of native-born Daviess County farmers. Volk effectively engaged his flock, but he also reached out to the German families of Owensboro. Volk performed his duties as pastor of St. Alphonsus while also serving a growing German congregation that met in an old brick building standing on West Third and Cedar Streets in Owensboro. ${ }^{62}$ These meetings and parishioners became the origin of the German congregation of St. Joseph. ${ }^{63}$ The German community of Owensboro slowly developed and organized. In 1869, several German families in the area started a German-language school to preserve "the faith and their German customs." The school's founders insisted that only German children could attend. ${ }^{64}$ The German community believed such a school necessary because Owensboro lacked public schools. An English-language Catholic school, St. Francis Academy, opened in 1849, but most Germans thought that instructing their children in English would make them more likely to become isolated from their ethnic community. ${ }^{65}$ The

\footnotetext{
${ }^{60}$ Russwurm, Volk, 5.

${ }^{61}$ Ibid., 5-6.

${ }^{62}$ Diocese of Owensboro, 24.

${ }^{63}$ Ibid. See also Wilkerson, That All May be One, 59.

${ }^{64}$ Wilkerson, That All May be One, 59.

${ }^{65}$ Patterson, "Catholic Church in Daviess County"; see also Conzen, Immigrant Milwaukee, 181.
} 
local German population also valued fraternity and formed a Hubertus Society. Prior to the arrival of Volk, a rabid dog bit Henry Rose, a member of the local German community. Many believed Rose was "sure to die," but he prayed to St. Hubertus, a revered saint among Germans, promising to start the society in the saint's honor if he survived. ${ }^{66}$ After he miraculously recovered, Rose established the group and became its first president. ${ }^{67}$ The group functioned primarily as a German Catholic benevolent society, providing aid to the sick. It also offered its members a sense of belonging and German community.

St. Joseph's, the new German-language school, opened in 1868 and was conducted in a traditional German manner. The headmaster, Nem Hamesser, taught reading, writing, and arithmetic. A stern teacher, he administered harsh discipline. One of his former students, Mary Tennes Oberst, recalled that he was "very cruel to the children," punishing them by pinching until they bled. Volk guided religious instruction at the school and took a special interest in the musical pursuits of the students. He sang hymns and national anthems with the children in both English and German, although his voice was "harsh and unmusical." ${ }^{98}$ Shortly after the German school commenced instruction, Owensboro's first public school opened. ${ }^{69}$ In an effort to draw German children away from St. Joseph's school and revealing the devotion of German immigrants

\footnotetext{
${ }^{66}$ Eugene Spiess, "Brief History of St. Josephs Parish,” St. Joseph Collection, Mount St. Joseph Archives, Maple Mount, Kentucky.

${ }^{67}$ History of Daviess County, 389.

${ }^{68}$ Oberst, "Father Volk Organized St. Joseph's, Owensboro", 1, St. Joseph Collection, Mount St. Joseph Archives, Maple Mount, Kentucky. Oberst's narrative specifically states that national "anthems" (plural) were sung in English and German. Volk may also have taught and sang German nationalist songs with the students.

${ }^{69}$ Oberst, "Origin of St. Joseph's Church," 2-3.
} 
to their mother tongue, the charter of the public school required that it offer students instruction in the German language..$^{70}$

Volk gained the confidence and admiration of local Germans and he soon became a leader of the community. He learned about their grievances against fellow Catholics, especially the segregation of St. Stephen. The local Irish also refused to associate with the Germans. ${ }^{71}$ In response, an infuriated Volk urged his fellow Germans to erect their own church where they could worship freely. ${ }^{72}$ However, Germans still faced persecution from Owensboro's nativist media, which targeted the German community. ${ }^{73}$

Owensboro's Protestant Germans also ostracized Catholics. When they established the German Order of Harugari, modeled after the Free Masons and the Oddfellows and rooted in Germanic paganism, they did not permit Catholics to join. ${ }^{74}$

The plan to erect a German church in Owensboro gained broad favor among German Catholics and Volk began discussions with Bishop McCloskey about the effort. He also started raising funds among German Catholics. In May 1871, the community held a fundraiser at Paradise Garden, an event that celebrated German culture and

${ }^{70}$ History of Daviess County, 362-63. See also Hawgood, Tragedy, 109. Hawgood noted that preservation of "German civilization and the German language" were primary concerns for German immigrants to the United States.

${ }^{71}$ Oberst, "Origin of St. Joseph," 2-3. Oberst attested that "the German and Irish did not get along; the Irish Catholics considered themselves better than the Germans and 'looked down upon them and did not want to mix with them.",

72 "Brief History of St. Joseph's Parish, Owensboro, Ky," The Record (Louisville), April 7, 1938.

73 "A Protest: From German Citizens of Owensboro against a Series of Unfounded Aspersions," Courier-Journal (Louisville), March 8, 1873.

74 "The Order of Harugari: It was Founded in New-York on German Mythology. Started for Defense - Perpetuated for Charity. Its Lodges Are Found in Nearly All the States, and Its Benefits Have Been Felt Throughout the Land-A Sketch of the Order," New York Times, August 25, 1895. 
revealed the economic status of the community. A large turnout enjoyed an event filled with drinking and merriment. Picnic-goers ate ham, pickles, slaw, crackers, cheese, and other German items "in abundance," though the food was not of the highest quality. An attendee partaking of the same fare at another picnic held days later recalled that the ham was fatty and the ale undrinkable. ${ }^{75}$ In fact, Volk served mass wine to those who found the beer unpalatable. But the picnic still raised a substantial amount of money and fundraising was "carried on enthusiastically by the people." Many in the community gave all they could. One widow, who made seventy-five cents a week ironing, contributed twenty-five cents weekly. Building the church proved all the more impressive in light of the humble origins of its parishioners. The community's efforts bore fruit and the German Catholic church was raised in $1871 .^{76}$ Volk then returned to his work at St. Alphonsus. The new German church, St. Joseph, and its congregation were turned over to Father Ivo Schacht, the pastor of St. Stephen. Schacht remained the interim pastor, presiding over both St. Stephen and St. Joseph, until $1872 .^{77}$

Volk continued to carry out his priestly responsibilities. He delivered daily masses and tended to his flock at St. Alphonsus. In his spare time, he became a menial laborer, firing kilns and laying bricks for the new convent. He also collected one thousand dollars in donations. The Ursuline Sisters, who took over instruction after the convent's completion, contributed another three thousand five hundred dollars. ${ }^{78}$ The remaining

\footnotetext{
${ }^{75}$ Mary Tennes Oberst, "Dedication of St. Alphonsus' Church, May 14 or 16, 1871," St. Joseph Collection, Mount St. Joseph Archives, Maple Mount, Kentucky. See also "Brief History," The Record, April 7, 1938, where Volk recounted the working class status of his early parishioners.

${ }^{76}$ Diocese of Owensboro, 145-46.

${ }^{77}$ Wilkerson, That all May be One, Prolog III.

${ }^{78}$ Patterson, "Catholic Church in Daviess County," 134.
} 
fifteen hundred dollars came from Volk's personal funds. ${ }^{79}$ Locals soon began attributing miracles to Volk. While laboring on the convent, for example, the priest fired the kiln to bake a batch of bricks. When the bricklayers arrived to begin their day's work, they discovered that the bricks had not properly hardened and could not be used. Unable to work, they returned home. Noticing the lack of activity, Volk investigated and discovered that the bricks were unusable. He lit a small amount of kindling under the kiln, not really enough to craft bricks, and prayed over it. He then called the laborers back to the site, who returned out of respect for the priest. They were surprised to find that the bricks, formerly unusable, were now hardened and suitable for use. Onlookers who observed the event shared the story widely, bolstering Volk's reputation and strengthening local Germans' faith in him. ${ }^{80}$

After the convent's completion, Ursuline nuns traveled by flatboat from Louisville, arriving in Owensboro on August 14, 1874. Volk biographer Norbert Russwurm identified Mother Pia Schoenhofer and Sisters Johanna Froeber, Xavier Wurm, Margaret Algeier, and Martina Grundner as the initial teachers. ${ }^{81}$ By 1880 , the census recorded five educators residing at St. Joseph's Female Academy: Leandera Saveri, age thirty-eight, born in New York to Swiss parents; Alberta Kern, age thirty-two; Augusta Bloemer, age thirty-one; Froeber, now age fifty-two; and Colletta Tork, age twenty-five, all born in Germany. ${ }^{82}$ The first teachers arrived unannounced at the school

\footnotetext{
${ }^{79}$ Russwurm, Volk, 6

${ }^{80}$ Ibid., 5.

${ }^{81}$ Ibid., 8.

${ }^{82}$ United States Census, 1880, Familysearch.org, https://www.familysearch.org/ark:/61903/3:1:33S7-9YBX-93CV?i=22\&cc=1417683 (accessed Aug. 4, 2018). The cook and all the housekeepers at the convent were also from Germany.
} 
and were humbled by what they found. With the opening of the school only a month away, the convent walls were bare and it lacked provisions and furniture. According to Russwurm, the "poverty" the women beheld made their hearts waver. Nonetheless, emboldened by their faith and Volk's support, the nuns pushed through the hardships of those early days. ${ }^{83}$ After the construction of a church and a convent, the German Catholic community of Owensboro continued to grow and prosper. In 1873, Father Ivo Schacht organized St. Martin's congregation for the Germans of Rome, Kentucky, a settlement seven miles outside of Owensboro, in the southwest corner of Daviess County. ${ }^{84}$

In 1878, tragedy befell the German community in Owensboro. Lightning struck St. Joseph, the church at the heart of the German Catholic community, and it burned to the ground. More problematic, the congregation divided over how to respond. The bishop ordered that a temporary church be erected where the old church stood. Many congregants living "on the hill," the traditional neighborhood of the town's German community, wanted the church rebuilt in the same location. However, working class Germans living on the expanding west side of town wanted the church built in Owensboro proper. ${ }^{85}$ German residents of the west end faced a difficult commute to St. Joseph, traveling through an area that frequently flooded. The burning of the church offered an opportunity to relocate the new building in a more accessible location.

But the community remained divided between those who wanted to rebuild "on the hill" and those who favored relocation. Both groups feared that their opponents would

\footnotetext{
${ }^{83}$ Russwurm, Volk, 8-9. ${ }^{84}$ Ibid., 150.

${ }^{85}$ Lee A. Dew and Aloma W. Dew, Owensboro: The City on the Yellow Banks (Bowling Green, KY: Rivendell Publications, 1990), 65, 92. See also Dew, “Our People,” 20.
} 
refuse to contribute to the new building if their preferred location was not chosen. A group of men from the congregation traveled to Louisville to speak with Bishop McCloskey about the matter, but he provided little guidance. And the congregation's new pastor, Father Peter Haeseley, remained passive in the matter. After discussing various options, church leaders reached a compromise, building the new edifice at Fourth and Clay Streets, halfway between the "hill" and the proposed location favored by those who lived in the west end. ${ }^{86}$ Disputes such as these happened frequently in German faith communities, reflecting a cultural predisposition for spirited argument. Historian Reinhard R. Dorries argues that such divides prevented Germans from dominating the American Catholic Church. In contrast, Irish solidarity enabled that group to supplant the French as the dominant presence in the Church. ${ }^{87}$ German faith communities often fractured, crippling their ability to act cohesively.

The responsibility for raising funds for the new building fell to Father Haeseley. Though the Germans viewed the church as essential for the community, they struggled to raise money a second time. A well-regarded member of the church, Frank Kamuf, traveled to several surrounding states and solicited funds from German communities. One priest, after hearing Kamuf's plea, donated the schematics of an already constructed church. These became the basis for the new edifice of St. Joseph. ${ }^{88}$ However, local Germans eager to raise their church did so without the approval of the diocese, outraging Bishop McCloskey. The ensuing controversy soured the bishop on the German

\footnotetext{
${ }^{86}$ Patterson, "Catholic Church in Daviess County," 134. See also Diocese of Owensboro, 146.

${ }^{87}$ Dorries, "German Immigrants and the Church," 7.

${ }^{88}$ Wilkerson, That All May be One, 68. See also Diocese of Owensboro, 145.
} 
community of Owensboro. The bishop expressed his displeasure with the "small German congregation" through his subordinate Monsignor Michael Bouchet in late $1878 .{ }^{89}$ The bishop wanted to conduct business in person, not wishing to leave a written record of the unflattering dispute. ${ }^{90}$ Haeseley knew of the bishop's anger and directed all his questions to Bouchet because he feared McCloskey's response. Haeseley asked the bishop to bless the church at the laying of its new cornerstone, but Bouchet informed him that McCloskey would not attend or officiate, nor would he ask anyone else to do so. ${ }^{91}$

${ }^{89}$ Monsignor Michael Bouchet to Reverend Peter Haeseley, November 13, 1878, Diocese of Owensboro Online Archive, https://owensboro.pastperfectonline.com/archive/412F149C-9982-4938-A757574886516859 (accessed July 10, 2017).

${ }^{90}$ Monsignor Michael Bouchet to Reverend Peter Haeseley, May 7, 1879, Diocese of Owensboro Online Archive. The bishop wanted nothing to be said of an inquiry made to him by Haeseley. Bouchet stated, "In reply to this he requested me to tell you that he would have to visit Owensboro, \& then he could talk you personally."

${ }^{91}$ Monsignor Michael Bouchet to Reverend Peter Haeseley, May 3, 1879, Diocese of Owensboro Online Archive. 


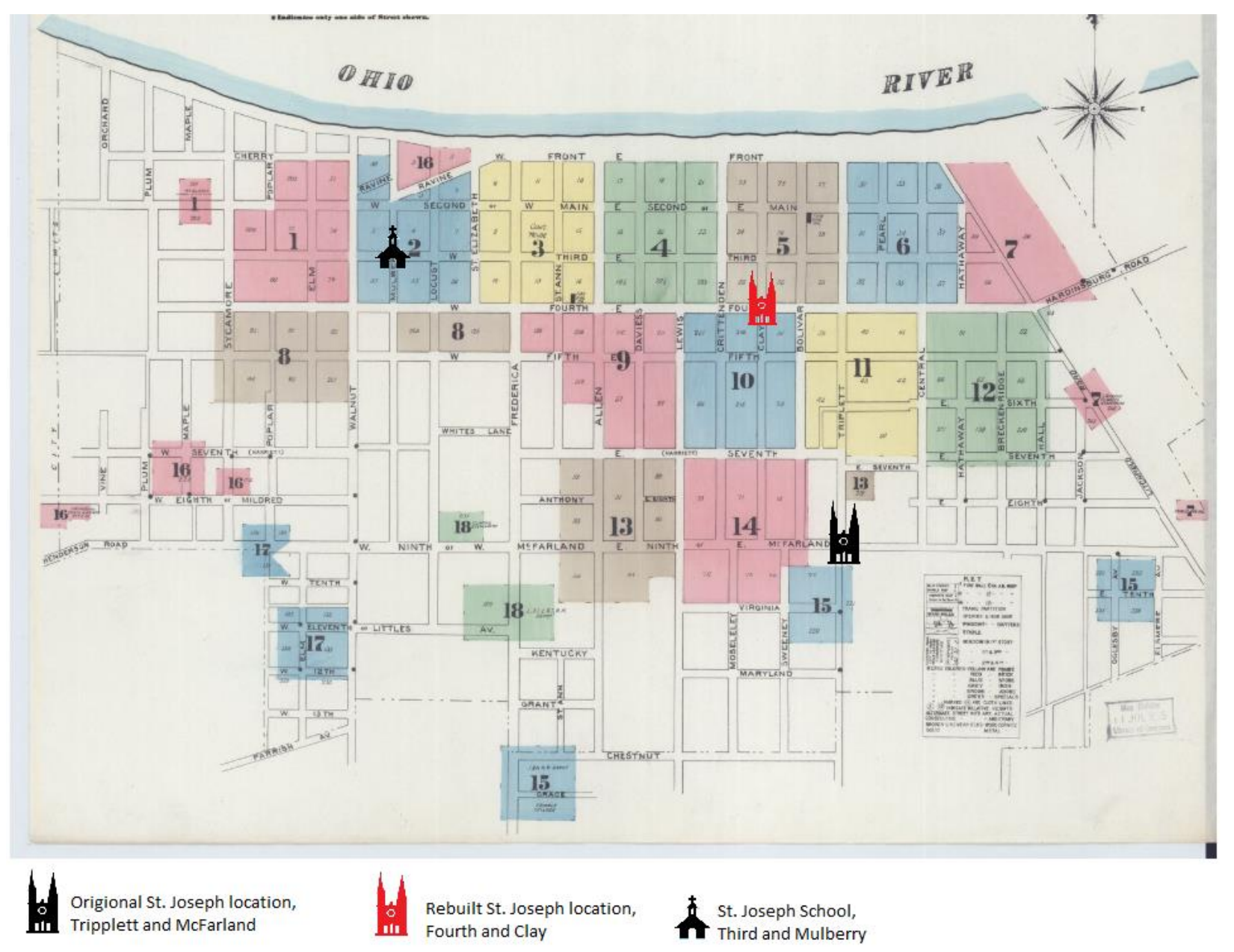

In 1879, an enraged McCloskey lambasted Haeseley, stating, "I regret to say that I cannot have anything to do with the new church until the debt shall have been paid. The building of this edifice was begun not only without my permission, but even in direct opposition to my wishes." He continued, "I foresaw that a debt would be created, \& I was unwilling to embarrass myself $\&$ the congregation with a debt which they could not perhaps ever pay." McCloskey argued that the German community's decision to assume a large debt affected the entire diocese. Angered by the congregation's actions, he informed Haeseley, "As soon, then, as the debt has been fully paid, you may call on me, but not till then." The edifice would not receive his blessing and mass was not to take 
place until the debt was paid. The German community, eager to erect their new building, disregarded the church hierarchy. The Germans built their church, but in response McCloskey proved unwilling to burden the diocese with the resulting debt. He told Haeseley that he would not put his "head in the noose" after their insubordination. ${ }^{92}$

The bishop's council adjudicated the matter, ruling in favor of the German community and approving the German church. However, it also decided that the diocese would not pay for the church nor would it take responsibility for the debt. McCloskey concluded that there was little he could do to stop Owensboro's German community. They built the church, and his only reasonable course was to forgive the congregation and move forward. But McCloskey assured Haeseley that the case ended in favor of the Germans only out of necessity and did not represent a validation of the congregation's actions. He warned the priest to act more cautiously in the future, noting, "There can be little blessing connected with a work begun in spite of episcopal authority." 93 In 1879 , the church still owed three thousand of the original forty five hundred dollar debt. Bouchet informed Haeseley that parishioners should contribute additional personal funds to the church. ${ }^{94}$ Over time, local Germans donated enough funds and gradually repaid the debt. By 1880 , though the church was not fully completed, congregants once again celebrated mass in their church, the heart and symbol of their community. ${ }^{95}$

In 1884, with the German community firmly established, Volk was called away

\footnotetext{
92 Bishop William McCloskey to Reverend Peter Haeseley, October 30, 1879, Diocese of Owensboro Online Archive.

${ }^{93}$ Bishop William McCloskey to Reverend Peter Haeseley, November 27, 1879, Diocese of Owensboro Online Archive.

${ }^{94}$ Monsignor Michael Bouchet to Reverend Peter Haeseley, Dec 18, 1879, Diocese of Owensboro Online Archive.

95 Patterson, "Catholic Church in Daviess County," 134.
} 
from Daviess County. An increasing number of immigrants in rural areas sparked a growing need for German priests throughout Kentucky, including the German communities in Lincoln and Boyle Counties. ${ }^{96}$ After Volk's success organizing the Germans in Owensboro, Bishop McCloskey thought him the perfect candidate, and requested that he consider the "spiritually forsaken German people." Volk faced a difficult decision. His biographer, Norbert Russwurm, wrote that "Volk felt a natural pang of sorrow at the thought of leaving his beloved children." But the will of God and the call of the bishop superseded his personal interests. Volk accepted the appointment, writing, "I came not to do my will, but the will of Him that sent me." Volk left St. Alphonsus and St. Joseph, in 1885. Though sorrowful, he was also proud. Over fifteen years, he had given all he could for the German community of Owensboro. ${ }^{97}$

By the turn of the century, the German presence in Owensboro had grown substantially. First and second generation German Americans numbered 1,391, some 12 percent of Owensboro's 11,538 inhabitants. The community continued to marry within the group, though at a declining rate. Of the 281 marriages in the German community 122 of them were between Germans, thirty-one between Germans and Europeans not from Germany, and the remaining 128 were between native-born Americans and Germans. The higher rate of marriage outside the group — over 56 percent of Germans now chose partners not of German descent—reflected the community's increasing acculturation into Owensboro society by 1900.

\footnotetext{
${ }^{96}$ John J. Weisert, "Lemcke Visits Kentucky's German Colonies in 1885," The Register of the Kentucky Historical Society 75 (July 1977): 222.

${ }^{97}$ Russwurm, Volk, 17-18. See also Diocese of Owensboro, 25.
} 


\begin{tabular}{|r|r|r|r|r|r|}
\hline Year & Population & German population & German to German marriage & German to non-German marriage \\
\hline 1850 & 794 & 62 & 16 & 1 \\
\hline 1870 & 3453 & 432 & 57 & 15 \\
\hline 1900 & 11,538 & 1,391 & 122 & 159 \\
\hline
\end{tabular}

Though the German community had lost their most influential shepherd in Father Volk, it never succumbed to grief over the loss. Instead, the community enjoyed sustained growth and Germans continued to live by Volk's example. Indeed, the priest continued a guiding presence in the community, keeping in contact with his much-loved flock regularly through the remainder of his life. Volk persisted in his prolific missionary work in both North and South America until his passing on November 2, 1919, but Mount Saint Joseph remained his home. His final days were spent there, and he was laid to rest in its cemetery, in St. Joseph, Kentucky, along with his beloved mother, Elisabeth, buried a short distance away, in St. Alphonsus Cemetery. By the turn of the century, the Germans of Owensboro and Daviess County had crafted an identity uniquely German, Catholic, and American. They constructed educational facilities and churches, solidifying their regional presence and preserving their cherished language and culture. Even after Volk's departure the community continued to prosper. Rebuilding St. Joseph and sustaining German institutions revealed their unwavering dedication to preserving their German heritage and community. 


\section{CHAPTER TWO:}

\section{“WHISKEY PEOPLE” AND STABLE HANDS: THE ESTABLISHMENT OF THE}

\section{IRISH COMMUNITY}

Irish immigration and the Catholic faith became an amalgamated threat in the minds of many native-born Americans in the mid-nineteenth century. Over generations, IrishCatholics cultivated a unique identity that was both wholly Irish yet uniquely American. Unlike the fiercely insular Germans, the Irish strove to gain acceptance as Americans, as many scholars have argued. ${ }^{98}$ However, Irish migrants' competing national identities proved problematic. Although many migrants initially opposed settling in America, they eventually became comfortable with the idea of making the United States their home. They sought acceptance from their native-born peers, yet retained their Irish roots and customs. As a result, they found themselves ostracized in America. In an era of rising nationalism and anti-Catholicism, Irish Catholics received a poor welcome from the Protestant majority and nationalist German Catholics. Irish Catholics in Daviess County proved no exception to this pattern.

Irish immigrants did not arrive in Owensboro in the same numbers as German

\footnotetext{
${ }^{98}$ Kenneth Moss, "St. Patrick's Day Celebrations and the Formation of Irish-American Identity, 1845-1875," Journal of Social History 29 (Autumn 1995): 125-26. See also Cian T. McMahon, "Caricaturing Race and Nation in Irish American Press, 1870-1880: A Transnational Perspective," Journal of Ethnic History 33 (Winter 2014): 35; and Jacobson, Whiteness, 209. For the insular habits of the German community, see Hawgood, Tragedy of the German American, 37. "Whiskey People" quote in title see Wilkerson, That All May be One, 1.
} 
immigrants during the antebellum era. Only thirteen Irish-born residents lived in the town in 1850 , compared to sixty-two Germans. ${ }^{99}$ As in large American cities, most Irish Catholics arrived in Owensboro impoverished and as a poor minority had difficulty establishing a permanent presence in the town. Still, the Irish eventually developed a tightly knit community and by the turn of the century represented the third largest white ethnic group in the town. They also established strong cultural and familial ties and eventually enjoyed significant economic success while proudly embracing their heritage. ${ }^{100}$

For most of the nineteenth century, the small Irish community in Owensboro faced a different situation than Irish Americans elsewhere. In many northern cities, the Irish overwhelmed other immigrant groups and became the dominant Catholic presence. ${ }^{101}$ Lacking such numbers, the Irish of Owensboro did not wield the same political power as their city-dwelling northern counterparts. They also did not control the church, a pivotal component of all immigrant communities. ${ }^{102}$ Germans' desire for farmland brought them to Daviess County, where land was plentiful, in large numbers. Most Irish, in contrast, sought urban environments where they met the demand for unskilled labor. In the 1850s, most Irish immigrants had survived the years of the potato famine in their homeland and any work was preferable to starvation. ${ }^{103}$

In addition, many Irish customs, including the social consumption of alcohol and

\footnotetext{
${ }^{99}$ U.S. Census Bureau, 1850 Kentucky Census.

${ }^{100}$ Dew, "Our People," 19.

${ }^{101}$ Reginald H. Pitts, “'Suckers, Soap-Locks, Irishmen and Plug-Uglies': Block 160, Municipal Politics and Local Control," Historical Archaeology 35, no 3: "Becoming New York: The Five Points Neighborhood" (2001): 91.

${ }^{102}$ Higham, Strangers, 15.

103 Jay P. Dolan, “The Irish Parish,” U.S. Catholic Historian 25 (Spring 2007): 14.
} 
public displays of emotion, seemed backward to many native-born Americans, who also decried the often wretched economic conditions of the Irish. By the late 1860s some white Americans even considered the Irish less advanced than the newly freed slaves. ${ }^{104}$ Even many fellow Catholics ostracized the Irish. In Owensboro, German and the nativeborn Catholics isolated the Irish, offering them little reprieve from their social exclusion. Despite their meager means and low social status, over time a strong community and Catholic identity enabled the Irish to establish a foothold in Daviess County.

The exclusions and struggles faced by the Irish in Owensboro reflected the experience of Irish immigrants in nineteenth century America. Most Irish immigrants, at least after 1840, arrived in America not by choice but out of necessity. Irish Catholics tended to stay in Ireland as long as possible rather than opt for the unknowns of emigration or they had no way of escaping the economic problems they experienced in their homeland. For example, in 1740, known as the bliadhain an air or the "year of slaughter," between two and four hundred thousand Irish peasants starved to death rather than emigrate. Only the potato famine of 1845 convinced larger numbers of Irish Catholics to abandon Ireland for life in America. Irish historian Kirby A. Miller suggests that the Irish attachment to the land explains their unwillingness to emigrate. He also attributes the Irish Catholic flight of the 1840s and 1850s to the improvements in and the

\footnotetext{
${ }^{104}$ Hawgood, Tragedy of the German American, 37. See also William A. Russ Jr., "AntiCatholic Agitation during Reconstruction," Records of the American Catholic Historical Society of Philadelphia 45 (December 1934): 315. Russ's article argues that many nativeborn Protestants viewed freed African Americans as better citizens than Catholic immigrants. They supported black suffrage as a right and a means to counterbalance "Romish" influence. See also Thomas Nast, "The Ignorant Vote-Honors are Easy," Harper's Weekly, December 9, 1876.
} 
growing affordability of overseas travel. ${ }^{105}$ Between 1845 and 1854 , nearly a million and a half Irish Catholics crossed the Atlantic for the United States. In these ten years, nearly five hundred thousand more Irish arrived in America than in the prior thirty years. Moreover, the Irish immigrants before 1845 were largely Protestant. ${ }^{106}$ The Catholic faith and impoverished state of Irish immigrants after 1845 helped shape native-born Americans' view of these migrants. Irish Catholics' attachment to their native land and culture also affected their experience in America.

The 1850 census of Owensboro offers a clear portrait of the thirteen Irish-born residents who lived in the town. Unlike their German counterparts, most of the Irish were young, single, and male laborers. The census identifies only four exceptions. Francis Dickson was fifty-one, married with five children, and a well-established clerk. He owned real estate valued at four thousand dollars, a substantial amount in the area. Dickson's success and surname identify him as a Protestant who arrived before the famine. The other three exceptions were women. Eliza Cochran, born in Ireland, married a Pennsylvania-born brick mason and had three daughters, while two Irish-born women were listed as residing at St. Francis Academy, the Catholic school established in 1849. The remaining Irish residents were laborers, ditchers, or ostlers (stablemen). Unwed and young, with a median age of twenty-six, all lived in rented accommodations. ${ }^{107}$ In the U.S. South, Irish-Catholic men usually became laborers. Thousands of Irish Catholics, fleeing famine and death, reached antebellum America with few marketable skills, aside

${ }^{105}$ Kirby A. Miller, Emigrants and Exiles: Ireland and the Irish Exodus to North America (New York: Oxford University Press, 1985), 142.

${ }^{106}$ Lawrence John McCaffrey, The Irish Catholic Diaspora in America (Washington, D.C.: Catholic University of America Press, 1997), 64-65.

${ }^{107} 1850$ Kentucky Census. 
from their strong backs. They often arrived in southern towns by the hundreds to work on public works projects. ${ }^{108}$ These short-term labor arrangements often resulted in a migrant life and a growing number of Irish Catholics found their way to the river town of Owensboro as a result.

The poverty of these early newcomers contributed to their lowly status. Young, poor, and often desperate Irish-Catholic men stood near the bottom of the American social hierarchy. Their cultural practices, including drinking, wailing at funerals, and Catholicism, led many native-born Americans to view the newcomers as dirty, drunken, and violent. Popular portrayals of Irish Americans in the nineteenth century often focused on their drunkenness and the resulting tragedies. ${ }^{109}$ An 1837 article in the Louisville newspaper, for example, described Irish parents so drunk they dropped their baby in a fire and helplessly fumbled about as it burned to death, screaming torturously. ${ }^{110}$ An article from the 1880s likewise described a "devoted but drunk" Irish wife who after delivering a meal to her imprisoned husband was run over by a train. ${ }^{111}$ Native-born Americans believed such tragedies common among the Irish, a result of heavy drinking habits that proved their inferiority to other whites.

The Catholic faith of the Irish reinforced such prejudices, as did their unfamiliar folk customs. Many native-born Americans, for example, found Irish wakes unsettling.

\footnotetext{
${ }^{108}$ Maes, Nerinckx, 224. Nerinckx described "three hundred Irishmen, mostly Catholics" working on a sixty foot wide, twenty mile long stone road. See also, Martin Crawford, ed., William Howard Russell's Civil War: Private Diary and Letters, 1861-1862 (Athens: University of Georgia Press, 1992), 71. Russell discussed the practice of employing Irishmen for arduous labor that was "death on negros and mules."

${ }^{109}$ McMahon, "Caricaturing Race and Nation," 33.

110 "Horrible Consequence of Intemperance," Louisville Daily Journal, March 21, 1837.

111 “Devoted but Drunk," Courier-Journal (Louisville), July 31889.
} 
The Irish publicly mourned their dead by crying and wailing, and the generous use of libations. Their wakes, at least as described in the nativist press, became hedonistic displays of woe, with mourning made a spectacle and drunkenness the primary goal of the vigil. The nativist newspapers described mourners so overcome with drink and emotion they trampled on the body of the deceased. Such rituals, reported in exaggerated fashion in anti-immigration publications, became infamous among native-born Americans even though the vast majority had never witnessed Irish mourning rituals. Nativist outlets spread such accounts widely, depicting the Irish and their wakes as barbaric, chaotic, and blasphemous. Such reports depicted a drastic divide between the cultural practices of native-born Americans and Irish Catholic immigrants. ${ }^{112}$ They also led many native-born Americans to question Irish "whiteness." In How the Irish became White, Noel Ignatiev asserts that most native-born Americans did not consider the Irish white, but instead placed them in a similar social status as African Americans. According to Ignatiev, African Americans and the Irish shared a "common culture of the lowly."113

However, some contemporary publications and current scholarship undermine Ignatiev's claims. Physician and nineteenth century race theorist John H. Van Evrie detailed the physical characteristics of whites and placed the Irish among pale-skinned, bearded "Caucasians." He also attacked whites who helped African Americans rather

\footnotetext{
${ }^{112}$ For exaggerated reports from an anti-immigrant publication, see "An Irish Wake," American National, February 20, 1880. For a more balanced report, see "The Irish Wake: It is a Kindly and Humane Custom in Intention," Courier-Journal (Louisville), October 18, 1898. For additional information on the Know Nothings, see Tyler G. Anbinder, Nativism and Slavery: The Northern Know Nothings and the Politics of the 1850s (New York: Oxford University Press, 1992).

${ }^{113}$ Noel Ignatiev, How the Irish became White (New York: Routledge, 1995), 3.
} 
than the less privileged members of their "own race" like the Irish. ${ }^{114}$ Evrie referred to Catholic Irish who suffered during the famine as "unfortunate white people." 115 Likewise, historian David T. Gleeson disputes claims that antebellum Americans perceived the Irish as "black," arguing that "the Irish always were 'white' and had no major problems with the dominant racial system in the region." $" 16$ The Irish faced hostility in the United States, but Ignatiev's claim that native-born whites viewed them as non-white before the liberation of the slaves is unsustainable. Native-born Americans' ostracism of the Irish resulted from national identity politics, religious prejudice, and the impoverished state of Irish Catholics both in their homeland and in America.

In contrast, fellow Catholics segregated the Irish because of their ethnicity. German and native-born Catholics viewed their cultures as superior to that of the Irish. ${ }^{117}$ They portrayed the Irish as filthy, drunk, ignorant, and unfit for association with decent citizens. As a result, Owensboro's Catholic community ostracized them, even within the Catholic churches. The congregation of St. Stephen segregated the Irish in the back pews, while St. Joseph did not allow Irish congregants to become members. It would take decades before American Catholics viewed themselves as members of a universal community sharing a similar identity. In an era of intense nationalism, immigrant communities formed around the culture and identity of the ethnic group and the church

${ }^{114}$ John H. Van Evrie, Negroes and Negro "Slavery": The First an Inferior Race; the Latter Its Normal Condition (New York: Van Evrie, Horton, and Co., 1861), 27-29. ${ }^{115}$ Ibid., 325.

${ }^{116}$ David T. Gleeson, The Green and the Gray: The Irish in the Confederate States of America (Chapel Hill: University of North Carolina Press, 2013), 16.

${ }^{117}$ Lawrence J. McCaffrey, "Irish Textures in American Catholicism," The Catholic Historical Review 78 (January 1992): 1. 
community existed as an extension of the ethnicity. ${ }^{118}$ In short, Irish Catholics shared the same faith as native-born and German Catholics but they did not belong to the same community. ${ }^{119}$

Protestants, likewise, viewed Irish Catholics as inferior and ignorant, though for different reasons. Unlike Catholics, Protestants grounded their prejudice primarily on religious rather than ethnic identity. Protestant preachers and thinkers attributed Irish Catholics' apparent ignorance to their faith, rather than their ethnicity. ${ }^{120}$ Many who condemned the Irish shared this prejudice. In The Papal Power in Politics, or Rome against Liberty, Owensboro preacher Benjamin Franklin Orr blamed Irish character flaws on their Roman Catholic faith. Orr questioned why the Irish Protestant immigrant became a "merchant, tradesman, mechanic, or professional man" while the Irish Catholic immigrant was "found with his spade and pick, and knowing little else than how to use them." He argued that Irish Catholics were "held in the most abject ignorance by the priest in order to keep them in the Catholic Church." ${ }^{121}$ New York nativist Dexter A. Hawkins, a great influence on Orr's work, concurred, stating that "the Irish race" had been subject to "the slough of ignorance, idleness and bigotry into which centuries of priestly instruction had brought them." ${ }^{122}$ Both men believed that the removal of Catholic priests would enable the Irish to rise in status in America.

\footnotetext{
${ }^{118}$ Maes, Nerinckx, 146. Nerinckx spoke of three congregations: "Germans, Americans, and Irish."

${ }^{119}$ Timothy M. Matovina, "The National Parish and Americanization," U.S. Catholic Historian 17 "Americanism and Americanization: Essays in Honor of Philip Gleason" (Winter 1999): 46.

${ }^{120}$ McCaffrey, "Irish Textures," 2.

${ }^{121}$ Benjamin Franklin Orr, The Papal Power in Politics, or Rome against Liberty (Owensboro: n.p., 1881), 193-94.

${ }^{122}$ Ibid., 173.
} 
Rejected by both Catholics and Protestants, Irish Catholics in Owensboro built their own faith-based community, built around a distinctive Irish-American identity, to survive and prosper. The process culminated in the founding of an Irish church, St. Paul, in 1886. The church reflected the growing prosperity of Owensboro's Irish Catholic community and stood as a testament to the group's resilience. From humble beginnings, not more than a handful of laborers, the town's Irish Catholics formed a thriving community. The years following the Civil War proved fruitful for Irish Americans. Though they did not completely escape hostility, the attention of most native-born Americans turned to matters more pressing than the "simian" Celt. ${ }^{123}$ The physical and economic damage of the war, the divided nation, and the status of the newly freed black population weighed heavily on the minds of many Americans. The growth of the second generation of Irish Americans, chain migration, and the migration of the Irish out of northern cities fueled the increase in the Irish population of western Kentucky. But unlike their German counterparts who flourished after the war and the arrival of Father Volk, Owensboro's Irish did not experience similar success for some decades.

Little evidence survives prior to the war to indicate that Owensboro's Irish shared a common identity. The Irish participated in the life of the Catholic community of Owensboro and attended mass as active Catholics, in part because of the presence of influential Irish-born clergy such as Father Eugene O'Callaghan. ${ }^{124}$ However, the Irish worshiped from the back pews of segregated St. Stephen. It took decades of population growth before the Irish established a sizable community in the town and not until the

${ }^{123}$ McMahon, "Caricaturing Race and Nation," 33.

${ }^{124}$ Diocese of Owensboro, 22, 27 
1880s did they form a distinct group. The slow progress of the Irish community can be attributed to the poverty of its members and their weak voice in existing Catholic churches, a primary supporter of immigrant life. ${ }^{125}$ In contrast, the Germans constructed numerous educational, spiritual, and cultural institutions prior to the establishment of St. Paul. After 1880, patronage from local distillers and Irish nationalism enabled the Irish community to develop more fully.

Irish nationalism emerged as a concern for Irish Americans in the 1880s. Numerous Irish nationalist land leagues, committed to dismantling the holdings of Anglo landlords, formed in the 1860s and 1870s. By the 1880s, the nationalist fervor stretched across the Atlantic to the United States. The movement connected the native Irish to migrants of Irish descent around the globe, though it garnered little support from Irish Protestants. In contrast, it received unanimous support among Catholics, ${ }^{126}$ leading Irish Catholics in the United States to view themselves as part of an "international imagined community." ${ }^{127}$ Irish nationalism thus melded Catholicism and Irish identity. As historian Lawrence J. McCaffrey explains:

Despite the aims of Irish cultural nationalism, it never has attracted the allegiance of Irish Protestants, who define Gaelic or Irish-Ireland as Catholic Ireland. Contradicting the inclusive ambitions of both political and cultural nationalists, Catholicism has remained central to Irishness. Since Gaelic nationalism and Catholicism have shared a distrust of the contaminating influences of the outside world, they have tended to become singular rather than separate approaches to Irish identity. ${ }^{128}$

${ }^{125}$ Dolan, "Irish Parish,” 14-15.

${ }^{126}$ Matthew Frye Jacobson, Special Sorrow: The Diasporic Imagination of Irish, Polish, and Jewish Immigrants in the United States (Cambridge, MA: Harvard University Press, 1995), 124. See also James J. Green, "American Catholics and the Irish Land League, 1879-1882," The Catholic Historical Review 35 (April 1949): 41.

${ }^{127}$ McMahon, "Caricaturing Race and Nation," 35.

${ }^{128}$ McCaffrey, "Irish Textures," 6. 
The nature of Irish-American identity in the United States-specifically the link between Irish nationalism and Catholicism—-meant that Irish Catholics could not easily shake their image as uneducated and backward immigrants among the Protestant majority. Native-born Americans' fear of Catholicism imperiled Irish Catholics whose ethnic identity remained inseparable from their religious identity.

Irish fraternal groups and the land league movement fueled the growth of a distinctive Irish Catholic community and identity in Owensboro. The Irish community also became more publicly visible. The Louisville Courier-Journal, for example, reported that a "large and enthusiastic" crowd gathered at Owensboro's courthouse for the first meeting of the "Daviess County Branch of the Irish Land League" on May 7 , 1881. The meeting established and organized the branch, elected officials, and secured ties to the Land League in Louisville. The group stood in unison with the "faithful Irish" to oppose "the heartless tyranny of the British Government." 129 Forty-two citizens signed their names on the first roll. ${ }^{130}$ The men selected to head the Davies County Land League were leaders of the Irish community. Elected as president, James D. Shortell was an Irishborn lawyer who at the age of six immigrated to America with his parents, James and Mary. Shortly after arriving in 1849, Shortell and his parents settled in Owensboro, though he later returned to Ireland with his mother for a short period. Returning to Kentucky in 1865, Shortell served as provost marshal in the U.S. Army and worked for the Internal Revenue Department. In 1876, Shortell moved back to Owensboro, one year after being admitted to the bar, and worked as a bookkeeper and cashier for the whiskey

129 "A Branch of the Irish Land League Organized," Courier-Journal (Louisville), May $12,1881$.

${ }^{130}$ History of Daviess County, 306. 
company R. Monarch and Company until 1882. He later provided the same services for whiskey distiller Miles P. Mattingly. When he was elected president of the land league, Shortell worked as an attorney for area distillers, "representing their interest in Washington." 131

The crowd elected Reverend Patrick M. J. Rock vice-president. Born in Ireland in 1850, Rock was educated in his homeland and immigrated to the U.S. in 1870. Ordained in Louisville by Bishop McCloskey, he taught at the Louisville Seminary and served as a priest for several different churches in the region. ${ }^{132}$ Edwin P. Millett was elected secretary. Unlike his counterparts, Millett did not hail from Ireland, but he was of Irish descent and a proud and active Catholic. He boasted that all his ancestors were Catholic and that he was one of two elected state representatives for the Catholic Knights of America, a Catholic fraternal order primarily focused on insurance. ${ }^{133}$ Millet lost his parents at an early age and was raised by relatives in Henderson, Kentucky. He had limited schooling but found employment as a clerk on several riverboats. Millet was later hired by the Monarch distilling family, to whom he proved himself highly resourceful. The former orphan later established the distilling firm of E. P. Millet and Company with Richard and William H. Monarch. As a successful businessman, Millet became a public voice of the Irish-Catholic community. ${ }^{134}$

The Irish community of Owensboro viewed these civic leaders as suitable representatives of the community. Many native-born Protestants, however, viewed these

\footnotetext{
${ }^{131}$ Ibid., 140.

132 Ibid., 627.

133 Ibid., 289.

${ }^{134}$ Ibid., 475.
} 
men as heretical peddlers of liquor and servants of the pope who infected the town and the country at large. ${ }^{135}$ Protestant fraternal groups such as the Free Masons, Knights of Pythias, Sons of Temperance, and Temple of Honor, promoted an anti-Catholic and temperance agenda and shaped political life and civic standards in Owensboro. They viewed the land league as further proof that the Irish, the pope, and the liquor trade were inseparable and posed a threat to the morals of the town.

The formation of the land league played a central role in the development of the Irish American identity. In the late nineteenth century many Irish Americans, particularly in rural areas, began to ponder their place in the United States. ${ }^{136}$ They had arrived in America in the 1840 s and 1850 s as exiles in a foreign place, and most turned to manual labor to survive. Many fully intended to return home when circumstances permitted. ${ }^{137}$ Several decades later, however, these immigrants had become permanent residents in the United States. Most formed families and found in the United States what they never knew they sought: a home. But many also sought to reaffirm their Irish heritage in America. Time and community provided the Irish with opportunity. Abandoning their migrant lifestyle, most Irish immigrants settled in one place and experienced some economic success. In Owensboro, a few Irish moved into skilled positions. Daniel Dougherty, a well-established Irish-born tailor, owned a retail space worth ten thousand dollars. ${ }^{138}$

135 Orr, Papal Power in Politics, 59-61.

${ }^{136}$ Deirdre M. Moloney, "Land League Activism in Transnational Perspective," U.S. Catholic Historian 22 "Ireland and America: Religion, Politics, and Social Movements" (Summer 2004): 61.

${ }^{137}$ Miller, Emigrants and Exiles, 4-6.

1381870 Kentucky Census; 1880 Kentucky Federal Population Census Schedules: Cumberland, Daviess, and Edmonson Counties, Reel 0411 (Washington: National Archives Microfilm Publications), 23. 
Tailors John Murphy and Pat Pedly received hearty praise from the Kentucky Irish American which claimed they had "for years made all the latest style clothing for the fashionable men" of Owensboro. The Irish also found employment in distilling and several, including John Hanning and John W. McCulloch, established their own distilleries. The Kentucky Irish American also boasted that Owensboro's longtime fire chief, Charley Harris, had "good strong Irish blood in his veins." ${ }^{139}$ Success stories like these gave the Irish a growing reputation for industry.

The growth of a distinct Irish-American identity took place in Owensboro and across the entire country. Though many Irish resided in large cities, by the late nineteenth century small towns like Owensboro and rural areas like Daviess County became longterm residences for a growing number of people of Irish birth or descent. Family, success, and time prompted them to settle. The push for Irish land rights reflected the evolution of Irish identity in America. Living in a country where free men could purchase land, Irish Americans extended support to their kin back home who sought the same right. Though they made their home in America, Irish Americans maintained ties to the land and their kin in Ireland. Historian Cian T. McMahon argues that "in America . . . [the] Irish viewed their local struggles for equality as part of a wider drama between freedom and tyranny playing out on a global stage." ${ }^{140}$ Catholicism undergirded the land league and Irish American identity. ${ }^{141}$ Building a church thus became a central goal of Owensboro's IrishAmerican community.

139 “Owensboro: Representative Men of Irish Decent in Every Business and Industry Acquit Themselves with Credit," Kentucky Irish American (Louisville), June 29, 1901. ${ }^{140}$ McMahon, "Caricaturing Race and Nation," 33.

${ }^{141}$ Jacobson, Special Sorrow, 124. 
St. Paul became the Irish population's new spiritual home. Years of hard work and community building brought the church to fruition. The devout Irish who attended mass in the far pews of St. Stephen were humiliated. Their segregation highlighted their second-class status in America, even among Catholics. Their new church represented a declaration of accomplishment. Like the Germans before them, the Irish needed to raise funds for the church. Such ethnic churches became statements of social status for immigrant groups, frequently built in response to want rather than need. But such efforts required the collection of large amounts of money from the community. Most residents of Owensboro did not know how the money for St. Paul's was raised or who worked behind closed doors to provide it. But prior to the announcement of the construction of St. Paul, meetings took place out of the public eye between a number of Owensboro's influential whiskey barons and various Catholic leaders. ${ }^{142}$ A letter, dated December 4, 1886, sent by Bishop William McCloskey to Father Thomas F. Gambon, the future priest of St. Paul, reveals the plans the priests and business leaders laid out in secret.

McCloskey wrote that Owensboro distiller Martin V. Monarch had traveled to Louisville and spoken to him, adding: "Mr. M. V. has just left me and I trust he will soon bring the matter we have been speaking of to a conclusion." ${ }^{143}$ The meeting reveals Monarch's reputation among Owensboro's Irish-Catholic community and his close relationship to the diocese. As the orchestrator of the effort to build St. Paul, Monarch received private audiences with several Catholic leaders. McCloskey's letter also highlights the close ties between the Diocese of Kentucky and the liquor industry, a

${ }^{142}$ William George McCloskey to Thomas Gambon, December 4, 1886, St. Paul Collection, Diocese of Owensboro Archives, Mount St. Joseph, Owensboro, Kentucky. 143 Ibid. 
relationship often criticized by opponents of the Catholic Church. Alarm about the relationship between the Catholic Church and the liquor industry became so pitched that Catholic officials later publicly banned those associated with the whiskey business from serving in leadership positions in Catholic societies and the church. ${ }^{144}$

Gambon played a pivotal role in the Irish-American community of Owensboro and the construction of St. Paul. In less than a decade, he rose from obscurity to become the most powerful priest in Kentucky, the chancellor of the Louisville diocese, and the only monsignor in the state. ${ }^{145}$ However, his rise involved some controversy because it brought the state's Catholic hierarchy closer to the bourbon trade. A native of Ireland, Gambon and his family immigrated to Kentucky where he spent most of his life. ${ }^{146}$ The diocese selected Gambon to oversee the construction of St. Paul, though he was a young priest with relatively little experience. Construction of the church began soon after the public announcement on December 1886. Parish officials held their first business meeting on January 9, 1887. The four primary figures involved in the venture, Father Gambon, Monarch, Peter E. Payne, and John William Morton Field, attended. Monarch, Payne, and Field were prominent local distillers who dedicated themselves to the erection of the church. On July 6, 1887, Elizabeth Ann Monarch, the wife of M. V. Monarch, and Field, laid the church's first foundational brick. ${ }^{147}$ The local community formed the Altar

\footnotetext{
144 John Ireland, "The Catholic Church and the Saloon," The North American Review 159 (October 1894): 499. See also Official Service and Instruction Bookfor St. Paul's Parish of Owensboro, Ky. 1905-1910 (Owensboro, KY: Payne Printing Company, 1905), 1, St. Paul Collection, Diocese of Owensboro Archives, Mount St. Joseph, Owensboro, Kentucky.

145 “The Churches," Courier-Journal (Louisville), October 18, 1896. See also "Father Gambon a Monsignor," Courier-Journal (Louisville), January 3, 1897.

146 "Father Gambon," Courier-Journal, January 3, 1897.

${ }^{147}$ Wilkerson, That All May be One, 7.
} 
Society to raise money. Gambon later disclosed that local distillers provided the initial funds, with Monarch donating two thousand dollars, and Payne and Field each contributing one thousand dollars. ${ }^{148}$

The construction of the church reflected the growth of the Irish-American community of Owensboro. Three characteristics defined the community and made construction of the church possible. First, the community developed a clear ethnic identity grounded in the Land League and fraternal organizations. These groups promoted ethnic ties between anyone who identified as Irish. ${ }^{149}$ Second, the Catholic Church played a seminal role in shaping Irish-American identity. ${ }^{150}$ Finally, the community's economic stability enabled it to thrive. Most Irish remained laborers. However, local Irish residents found economic success, which gave the community the financial resources necessary to build the church. The Irish-American community of Owensboro became united under the moneyed and powerful patrons who controlled the distilling industry. Though many teetotaling Protestants disapproved of the whiskey business, it contributed greatly to the town's economic stability and growth. In short order, St. Paul became the focal point of the Irish community and the whiskey men remained the patriarchs of the Irish congregation. By the time the church was completed in 1889 , the distillers had firmly established themselves as the leaders and patrons of the community. Gone were the days when the Irish were corralled into the back pews of St. Stephen. The Irish now had a church of their own and standing at the top of the list of pew holders stood the Monarch,

\footnotetext{
${ }^{148}$ Father Gambon Interview, December 13, 1897, St. Paul Collection, Diocese of Owensboro Archives, Mount St. Joseph, Owensboro, KY. See also Service and Instruction Book, 1-2.

${ }^{149}$ Green, "American Catholics and the Irish Land League," 41.

${ }^{150}$ Ibid. See also Jacobson, Whiteness, 50.
} 
Payne, and Field families. ${ }^{151}$ The beautiful new church housed the Irish community's meetings, served as a sanctuary for their celebrations, and made them the equals of the native-born Americans of St. Stephen and the Germans of St. Joseph. ${ }^{152}$

However, the church's location upset many Catholics. Most Irish residents lived in the west end area known as Mechanicville close to the distilling, tile manufacturing, wood working, and meat processing factories that employed them. St. Paul, however, was not constructed in the west end of town, but instead near the German and native-born American communities on the east side of the town. Indeed, the Irish church stood less than a mile from St. Stephen and only a few blocks from St. Joseph. Many Owensboro residents worried that the Irish were encroaching on the other churches and their communities. Some local Catholics feared that Irish community leaders sought to establish their church as the dominant Catholic institution in the area. ${ }^{153}$ Historian Lee Dew suggests that the location of the church reflected the cheaper cost of the land on the east side and the construction of the town's new street car system which provided easy travel along Fourth Street. ${ }^{154}$ Perhaps all these reasons played a factor in deciding the location of the church, but its construction reflected the growing significance and permanence of the Irish Catholic population of Owensboro.

By 1900, the Irish community had grown significantly. Some 283 residents of Owensboro were first or second generation Irish American. Though the Irish community remained substantially smaller than the German population of the town, the Irish

\footnotetext{
${ }^{151}$ Service and Instruction Book, 7.

${ }^{152}$ Wilkerson, That All May be One, 11-12.

${ }^{153}$ Ibid., 1.

${ }^{154}$ Dew, “Our People," 20.
} 
nonetheless enjoyed significant growth and increasing respectability after the Civil War. ${ }^{155}$ In 1850 , nearly all residents of Irish descent worked as manual laborers. ${ }^{156}$ Fifty years later, the Irish found employment in a variety of endeavors. Skilled tradesmen such as plumber Mike McDermot, educator J. D. Kelly, and sewer pipe manufacturer Robert O'Connor stood as testament to the success of many of Owensboro's Irish residents. ${ }^{157}$ Irish women also entered the town's workforce, including seamstress Mary Enright, dry goods salesperson Margaret Thomas and her daughter, Matti Thomas, a kindergarten teacher. Irish women, many of them widows, often became the primary source of income for their working class families. Irish women also made up a substantial portion of religious women in the town. ${ }^{158}$ Eleven of the sixteen women who served as Sisters of Charity in Owensboro were of Irish descent. ${ }^{159}$ Thus, when the Kentucky Irish American ran an article about Owensboro's "Men of Irish Descent in every Business and Industry” it had plenty of evidence to support its claims. ${ }^{160}$

Owensboro's Irish Catholic community also enjoyed success because of their willingness to acculturate into the broader community. In contrast to Germans who practiced in-group marriage to a notable degree even at the turn of the century, the Irish married outside their ethnic community. In 1900, in only six of the forty-five marriages involving a person of Irish descent were both spouses Irish. In contrast, nine marriages

1551900 Kentucky Federal Population Census Schedules: Crittenden, Cumberland, and Daviess Counties, Reel 517 (Washington: National Archives Microfilm Publications, 1978).

1561850 Kentucky Census.

1571900 Kentucky Federal Population Census, 760, 782. See also "Representative Men of Irish Descent," Kentucky Irish American, June 29, 1901.

1581900 Kentucky Federal Population Census, 764, 656.

1591900 Kentucky Federal Population Census, 656.

160 “Representative Men of Irish Descent," Kentucky Irish American, June 29, 1901. 
involved Irish residents marrying another European and thirty were between Irish and native-born Americans. ${ }^{161}$ The Irish valued their ethnic community, as their participation in Irish organizations and clubs revealed. But they also ventured into the broader society in a variety of ways, encouraged by clerical leaders to imitate American customs and present themselves as devoted American citizens. In the process, they became Irish American. ${ }^{162}$ Indeed, the success of the local Irish community enabled a Louisville paper to hail Owensboro as the "place in Kentucky where Irish and Irish-Americans are loved and revered for their industry, honesty and general capability."163 The success occurred despite the fact that many Irish immigrants at first had no intention of becoming permanent residents and made little effort to establish permanent roots in their new home. As the Irish population grew, however, immigrants began to develop communities that celebrated Irish customs. Though often beset by hardship, many Irish began to feel more at home. In Owensboro, the rising economic prosperity of the Irish community, especially a few wealthy distillers, provided the funds necessary to build a church and solidify the community. The Irish made a home in Owensboro and their presence continued to grow stronger in subsequent years.

1611900 Kentucky Federal Population Census, 656.

${ }^{162}$ Service Book for St. Paul's, 5-7. See also "A Branch of the Irish Land League," Courier-Journal (Louisville), May 12, 1881.

163 "Representative Men of Irish Descent," Kentucky Irish American, June 29, 1901. 


\section{CHAPTER THREE:}

“THIS MOTHER OF HARLOTS”: OPPOSITION TO CATHOLICISM IN DAVIESS

\section{COUNTY}

"The history of the Roman Catholic Church is one of most vile corruption and intolerant bigotry, and of arrogant pretention to supremacy of power. Her ecclesiastical order is the most gigantic and dangerous monopoly the world has ever seen." 164 These two fiery sentences opened Owensboro minister Benjamin Franklin Orr's The Papal Power in Politics, or Rome against Liberty. Its 1881 publication was the culmination of Orr's legacy as a Methodist Episcopal preacher and opponent of the Catholic Church. Orr's words resonated with many and his book, local historians note, received wide circulation. ${ }^{165}$ Like many Protestants in Daviess County, Orr responded to what he saw as a Catholic attack on the United States. Traitorous Romanists and ignorant Irish led astray by the whore of Babylon, he believed, were destroying the country one town after another. Orr argued that Protestant Americans only had to observe the changes in the country and the truth of his words would be clear.

Anti-Catholicism and anti-immigrant sentiment erupted in the United States in the nineteenth century, but the tradition of anti-Catholicism had a long history in the United States. American anti-Catholicism was rooted in the Reformation and its intensity on the

164 Orr, Papal Power in Politics, 1.

${ }^{165}$ Graves County, Kentucky, History and Families. Paducah, KY: Turner Publishing Company, 2001,378. 
continent peaked and declined as circumstances changed. ${ }^{166}$ American colonists interacted with Catholics as enemies during the Seven Years' War in the 1750s and 1760s. French troops and their Native American allies terrorized colonists, igniting hatred for their Catholic enemies. ${ }^{167}$ American disdain for the French subsided after France allied with the United States during the American Revolutionary War. ${ }^{168}$ However, the seeds of anti-Catholicism remained firmly rooted in the New England states and the region's anti-papal writers stayed active during the early republic. In the nineteenth century, in the wake of the Second Great Awakening, evangelical Protestantism became a core element of American identity. As a result, another wave of anti-Catholicism erupted with the arrival of thousands of Catholic German and Irish immigrants in the 1830s and 1840s. The fear of invading Catholics sparked the Nativist movement. Indeed, historian John Higham identified anti-Catholicism and Anglo-Saxon supremacism as core aspects of antebellum American nationalism and Nativism. ${ }^{169}$

Historians have traditionally studied national leaders, including those who examine Nativism and anti-Catholicism. Scholars often cite figures such as Josiah Strong, Madison Grant, and Theodore Roosevelt as predominant thinkers of postbellum Nativist ideology. ${ }^{170}$ However, how Americans in rural areas like Daviess County with small

\footnotetext{
${ }^{166}$ Kyle E. Haden, "Anti-Catholicism in U.S. History: A Proposal for a New Methodology," American Catholic Studies 124 (Winter 2013): 27.

${ }^{167}$ Alfred A. Cave, The French and Indian War (Westport, CT: Greenwood Publishing Group, 2004), 73-74. See also, Haden, "Anti-Catholicism in U.S. History," 40.

${ }^{168}$ William J. Lallou, "Catholic Loyalty to America," Records of the American Catholic Historical Society of Philadelphia 62 (September 1951): 181.

${ }^{169}$ Higham, Strangers, 5-11.

${ }^{170}$ Ibid., 155-56. Higham called Madison Grant "intellectually the most important nativist in recent American history." See also Thomas G. Dyer, Roosevelt and the Idea of Race (Baton Rouge: Louisiana State University Press, 1992); and Alan Trachtenberg, The Incorporation of America: Culture and Society in the Gilded Age (New York: Hill and
} 
immigrant populations understood these ideas remains less clear. Still, anti-Catholicism emerged soon after the 1815 establishment of Daviess County, as the career of Baptist preacher Williams Downs reveals. Downs, along with his brother Thomas, became Baptist preachers in the county in the early nineteenth century. Downs was brash, dressed in a lavish manner, and became known for his outspokenness and fondness for "religious controversy." Soon after the county's foundation, he publicly challenged any Roman Catholic priest to match wits in a religious debate. ${ }^{171}$ The event garnered significant attention and drew hundreds. The response of local residents to the proposed debate reveals the depth of anti-Catholic feeling in the county.

After Downs issued his debate challenge, Daviess County's congressional representative John Calhoon spread word of the event in the region. ${ }^{172}$ Excitement grew as the day of the debate approached. Ultimately, a crowd of two thousand people gathered in the birch grove that Downs selected as the debate site. Downs waited for a Catholic challenger for an hour before he rose to address the crowd. After surveying the gathering and seeing no priests, Downs proclaimed, "Where, oh, where is the uncircumcised Philistine who assumes the power of the living God?" Downs's words produced "intense" "excitement," according to surviving reports, and "the air was rent by the shouts of the multitudes." Downs then preached a triumphant sermon, exultant that no

\footnotetext{
Wang, 1997), 78-79.

${ }^{171}$ History of Daviess County, 57-58.

${ }^{172}$ William B. Allen, A History of Kentucky: Embracing Gleanings, Reminiscences, Antiquities, Natural Curiosities, Statistics, and Biographical Sketches of Pioneers, Soldiers, Jurists, Lawyers, Statesmen, Divines, Mechanics, Farmers, Merchants, and Other Leading Men, of All Occupations and Pursuits (Louisville: Bradley and Gilbert, 1872), 117.
} 
Catholic priests had responded to his challenge. ${ }^{173}$ Neither he nor the crowd worried that the dearth of challengers likely reflected the fact that Catholic priests had not heard of the challenge. As Father Elisha J. Durbin, the "patriarch-priest of Kentucky" noted, no Catholic settlements existed in Daviess County as late as $1823 .{ }^{174}$ But this fact did not diminish either Downs or the large crowd's anti-Catholic enthusiasm. The role of a prominent politician, John Calhoon, in promoting the event also highlights the depth of anti-Catholicism in the region. One contemporary described Calhoon, a lawyer who served in Congress and as a circuit court judge, as "far superior to any man of his time." ${ }^{175}$ Calhoon's embrace of anti-Catholicism reflected and reinforced the sentiments of most Daviess County residents.

Thus, Orr's post-Civil War attacks on Catholicism reflected longstanding Daviess County attitudes. Born on August 5, 1848, Orr was raised in Graves County, Kentucky, close to the Tennessee border. He encountered Catholicism at an early age because Catholic settlers established many towns in Graves County, including Fancy Farms and Dublin, beginning in 1828. As a result, the county, along with the neighboring counties of Carlisle and Hickman, became known as the "Catholic Settlement." ${ }^{176}$ Still, the Catholic population of Graves and the surrounding counties remained relatively small, particularly in comparison to the growing Catholic population of Daviess County in the years following the arrival of Father Paul Joseph Volk in 1870.

\footnotetext{
${ }^{173}$ History of Daviess County, 58.

${ }^{174}$ Maes, Nerinckx, 221.

${ }^{175}$ History of Daviess County, 117.

${ }^{176}$ Ronald Colburn, "A History of Graves County" in "The Catholic Settlement": A History of St. Jerome Catholic Church, 1836-2011, ed. Cynthia Pierce Elder (Morrisville, NC: Lulu Press, 2012), 27.
} 
Orr's Protestant faith shaped his life and he committed himself to religion as a teenager. A gifted student, Orr excelled at school, though he attended only local institutions. His intellect and charismatic presence brought him attention and gave him the air of a "true Kentucky Gentleman," according to one local history. ${ }^{177}$ But the coming of the Civil War compromised the young man's opportunities and interrupted his education. During the war, both Confederate and Union armies occupied his small community and disrupted his life. In 1865, at the age of seventeen, Orr converted to the Methodist Episcopal faith and decided to pursue a career in the ministry. Within two years, the Reverend C. B. Parsons of Louisville had licensed Orr to preach. From the age of seventeen until his death fifty-five years later Orr dedicated his life to the Methodist ministry and anti-Catholicism. He also married four times and fathered nine children. ${ }^{178}$ Orr enjoyed significant local influence, in part because of his tireless efforts to spread his faith. He dedicated his life to the Methodist Church and disseminating his faith as broadly as possible. Orr sought every outlet to share his message. By the early 1880 s, he pastored three congregations in Daviess County: Bethlehem Methodist Episcopal Church; Salem Methodist Episcopal Church, South; and Methodist Episcopal Church, South. In 1882, seeking to spread his religious message more broadly, Orr joined the Reverends J. S. Scobee and G. H. Hays in producing a four-page, monthly news publication, the Methodist Standard. He also attended conferences and published several articles in national publications, including the Methodist Review. ${ }^{179}$ Orr's central theme, widely embraced by local Protestants, was the imminent danger the Catholic Church

177 Graves County, 378.

178 Ibid.

179 Ibid. 
presented to the United States.

Orr argued that Catholic conversion, immigration, and schooling must be stopped because the Catholic Church posed a threat to American ideals of liberty and the nation's system of government. In the United States, Orr argued, "every man is a sovereign ... and every child is heir to a scepter of power," free of "the control of the priestly hierarchy." 180 The Catholic Church, he contended, was an instrument of corruption determined to effect the submission of all worldly powers to the pope. The success of this Catholic enterprise, he added, depended on the conversion of people to the faith and the embrace of the doctrine of papal infallibility. These ends would be reached by the Catholic infiltration of public education and by "every true Catholic" opposing American law under the instruction of the pope. ${ }^{181}$ The pope's infallibility made him the true and only leader for all who accepted Catholicism. As a result, the Catholic Church stood as the "deadly enemy" of "the genius and spirit of civil and social institutions of the United States. $" 182$

Orr's message owed a great deal to his Methodist brethren in New England. In the late eighteenth century, much of Maryland's Catholic population migrated west of the Appalachian Mountains. However, they could not escape the anti-Catholicism that had long festered in the East. Many western evangelical leaders imported their xenophobic arguments from the East, particularly from New England. The growing population of German and Irish Catholics after the 1840s intensified the anti-Catholicism of American Protestants and western ministers. Like Orr, they carefully studied the writings of their

\footnotetext{
${ }^{180}$ Orr, Papal Power, 159.

${ }^{181}$ Ibid., 159-167, 26.

182 Ibid., 19.
} 
eastern colleagues to combat what they perceived as the growing threat Catholicism posed to the country. Though anti-Catholicism existed in Daviess County, Orr worried that many residents did not understand why the religion and its hierarchy was so dangerous. He worked hard to educate his congregations so that they comprehended the nefarious aims of the Church of Rome.

In the preface of his work, Orr acknowledged his gratitude to eastern ministers like the Reverend Granville Moody, a Maine-born Presbyterian, convert to Methodism, and outspoken anti-Catholic who authored Popery and its Aims. ${ }^{183}$ The Reverend Joseph Cook and the Honorable Dexter A. Hawkins also garnered special gratitude from Orr. Cook, a Boston native, acquired fame for his Monday Lectures, the published and circulated transcriptions of his famed Tremont Temple lectures, and Hawkins authored Expulsion of the Corruptions of Romanism in the Cities of New York and Brooklyn. ${ }^{184}$ Such writers helped inspire Orr to take up his pen and explain the nature and evils of the Catholic Church to his western and southern readers.

N. H. Lee, a fellow Kentuckian, wrote the introduction to Orr's book. Lee acknowledged that "a great deal" had "been written and published" on the "political pretentions of Rome" and that "the author brings forward nothing really new upon the subjects treated nor does he profess to do so." Lee also conceded the intellectual leadership of New England on the subject of anti-Catholicism. He lamented that "most of the treatises on this topic have been confined in their circulation to the North and East,

${ }^{183}$ Granville Moody, A Life's Retrospect: Autobiography of Reverend Granville Moody D. D. (Brigadier General by Brevet), ed. Rev. Silvester Weeks (New York: Hunt and Eaton, 1890), 21.

${ }^{184}$ Orr, Papal Power, 5. 
very few persons in the Southern States having read them." Well educated southerners recognized the threat posed by Catholicism, Lee noted, but Orr aimed his study beyond "the few" because everyone needed to know his anti-Catholic message. ${ }^{185}$ Thus, he emphasized the threat posed by the encroaching Catholic Church and sought to expose its covert means of indoctrination and expansion. According to Lee, the "Southern people need[ed] a work written by one of their own citizens, and from a stand-point a little different, it may be, from that from which other books have been written and consequently presenting the subject in a phase more likely to make it attractive to the people." Orr, then, stood on the frontline of a new regional battleground. Southerners confronted an enemy who was foreign in custom and often in origin and Orr made it his mission to inform them of the threat posed by Catholicism. ${ }^{186}$

Orr's book offered a compendium of anti-Catholic rhetoric, an overview of the most recent and accepted xenophobic thought promulgated by respected Protestant writers, including the threat posed by the doctrine of papal infallibility. But Orr's study also discussed the most pressing concerns of Daviess County residents, thereby increasing his local readership. Many Protestants in Daviess County and Owensboro nervously watched the establishment of Catholic institutions and schools, the first of which, St. Francis Academy, was opened in a former hotel in 1849 by five Sisters of Charity of Nazareth. ${ }^{187}$ Protestants worried that the opening of the parochial school would enable Catholics to convert the children of the community and they vehemently opposed it. Anna Blanche McGill, a historian of the Sisters of Charity of Nazareth,

${ }^{185}$ Ibid., 7-10.

${ }^{186}$ Ibid., 7-8

${ }^{187}$ Diocese of Owensboro, 21; Patterson, "Catholic Church in Daviess County," 133. 
argued that local hostility to the school placed the nuns in physical danger. These early "trials," McGill noted, "challenged the courage" of the founding nuns. The large Protestant majority of Daviess County and Owensboro did not welcome the Catholic newcomers and only in time would non-Catholics accept the institution. ${ }^{188}$

Orr contributed to the local hostility, arguing that the nuns and priests who established parochial schools did not want to advance education but instead sought to undermine liberty. The books read and lectures delivered in these schools, Orr contended, lacked educational value. Instead, schools like that established in Owensboro pursued the indoctrination of the youth who attended them. According to Lee, the Catholic Church's "professed zeal for the education of youth is only a pretense." "Her real object in securing the charge of youth . . . is . . to lead her pupils into the bosom of the Roman Church."189 As Orr explained, Catholic leaders' belief that the Catholic Church should guide all education posed an imminent danger because it stood "upon their claim that the Catholic is the only true form of religion; that Protestantism is no more than a form of infidelity." ${ }^{190}$ Orr's suspicion of Catholic education followed the anti-Catholic teachings of R. W. Thompson, an author to whom Orr was particularly indebted. Echoing Thompson, Orr wrote that "these schools, without any exception" taught "a higher allegiance to the Pope of Rome than to the Government of the United States." 191 Sensationalist popular literature also expressed suspicion of Catholic schools,

\footnotetext{
188 Anna Blanche McGill, The Sisters of Charity of Nazareth, Kentucky (New York: Encyclopedia Press, 1917), 112.

${ }^{189}$ Orr, Papal Power, 9.

${ }^{190}$ Ibid., 161-62.

${ }^{191}$ R. W. Thompson, The Papacy and the Civil Power (New York: Harper and Brothers, 1876), 20.
} 
echoing a widely accepted idea while inciting greater mistrust and hostility. The most infamous and best-selling of these sensationalist works was The Awful Disclosures of Maria Monk, initially published in 1836 . This inflammatory work purported to tell the story of a young girl who entered a Canadian convent and then confronted a dark world of forced sexual enslavement, infanticide, and murder. Historian Ray Allen Billington called this fabricated story "by far the most influential single work of American nativistic propaganda in the period preceding the Civil War." ${ }^{" 192}$ The book outraged Protestants, deepening their hatred of Catholics and drawing their attention to the closed doors of convents, seminaries, and Catholic schools. ${ }^{193}$ But Maria Monk followed in the wake of similar works. Published in 1835, Six Months in a Convent described the experiences of a young Charlestown, Massachusetts, Protestant girl lured into the habit only to find herself a prisoner of her new Catholic masters. As the Catholic press noted, this fictional tale stoked Protestant distrust and hatred of Catholics. Notably, a year before the publication of Six Months in a Convent a Protestant mob had rioted and burned down an Ursuline convent in Charlestown because they believed it held a young Protestant girl against her will. ${ }^{194}$ The anti-Catholic hysteria fueled by such works, along with the rhetoric of Protestant ministers, helps explain why the Sisters of Charity faced opposition when they opened St. Francis Academy.

Maria Monk represented the most infamous of anti-Catholic sensationalist

\footnotetext{
192 Ray Allen Billington, "Maria Monk and Her Influence," The Catholic Historical Review 22 (October 1936): 283.

193 Dennis Castillo, "The Enduring Legacy of Maria Monk," American Catholic Studies 112 (Spring-Winter 2001): 49-59

${ }^{194}$ William S. Cossen, "Monk in the Middle: The 'Awful Disclosures of the Hotel Dieu Nunnery' and the Making of Catholic Identity," American Catholic Studies 125 (Spring 2014): 30-31.
} 
literature, but similar tales continued to surface for decades thereafter. For example, in 1880, a year before Orr published his anti-Catholic screed, Amy's Probation saw the light of day. Though a fictional tale, its anonymous author claimed that it drew from the writings of Catholic educators. ${ }^{195}$ Moreover, it contained a litany of Protestant allegations against Catholic education. The story recounts the experience of a young Protestant girl sent to a Catholic school for young ladies along with her sister, cousin, and Milly, a family acquaintance. At first, the girls' parents question the intentions of the Catholic educators, believing that such schools sought to convert young women to "Popery." Milly, who the family knew as a good Protestant and had previously attended the school, insists that it posed no such dangers, and convinces the parents to send their daughters. Once at the school, however, the nuns separate the main protagonist, Amy, from her companions and she must defend her Protestant faith alone. The nuns attempt to indoctrinate Amy and her companions about the virtue of absolute and unthinking obedience. They employ every means to sway Amy, but she successfully combats their efforts to subvert her Protestant belief in individual reason. The girls escape the school after discovering that Milly, following the instructions of the Mother Superior, had deceitfully lured her friends to it. Unlike Amy, Milly had succumbed to the nuns' rhetoric of unquestioning obedience, renounced her Protestant faith, and secretly began preparations to become a nun. The Mother Superior instructed her to deceive her family and convince her friends to attend the school. The experience changes the girls. Amy becomes untrusting and reclusive, her cousin is unable to function normally, and Amy's sister denounces her faith and becomes a devout Catholic and a nun. The girls had spent

${ }^{195}$ Castillo, "Enduring Legacy of Maria Monk," 49-59. 
only six months in the school, but it nonetheless "spoiled" their minds. 196

The warning to Protestant readers of the threat posed by Catholic education could not be clearer. By the late nineteenth century, in towns across America, Catholics began erecting educational institutions. In many southern locales like Owensboro, these schools existed years or even decades before publicly funded institutions. Orr's book focused on the insidious nature of the Catholic influence on education. The content of sensationalized anti-Catholic fiction like Amy's Probation mirrored and reinforced Orr's claims. In these fictional works, just as Orr had warned, the Catholic Church demanded that allegiance to the pope supersede all other loyalties. Such blind obedience, Orr argued, turned children against their parents and citizens against their country. A good Catholic, he concluded, could retain loyalty to the pope alone. ${ }^{197}$ Men like Orr believed that only the vigilance of the Catholic Church's numerous opponents kept its influence and power in check. Much to Orr's delight he was not the only outspoken enemy of Romish influence in Daviess County.

“Colonel” Joshua G. Ford, known as "J. G." Ford, was born in Caldwell County, Kentucky, around 1831 (his exact birth date is unknown). Driven and headstrong, Ford, at the age of twelve, made the eighty-two mile journey from his home to Owensboro on foot, where he entered an apprenticeship with the printer of the Bulletin, the town's first newspaper. Established in 1844, the Bulletin supported the Whigs, reflecting the popularity of Henry Clay's party in antebellum Kentucky. Ford's decision to learn the

\footnotetext{
${ }^{196}$ Amy's Probation; or, Six Months at a Convent: An Answer to the Question, Shall Protestant Girls Be Sent to Roman Catholic Schools? (New York: Phillips and Hunt, 1880).

197 Orr, Papal Power, 54-55.
} 
profession of printer enabled him to become a prominent local newspaperman and politician. In 1856, Ford began co-editing a newspaper, the National American, with fellow Owensboro resident George H. Yeaman, that supported the Know Nothing (or American) Party. As editor, Ford repeatedly took the limelight. Often a demagogue, his anti-Catholic words and actions frequently sparked public outrage and on one occasion led to his imprisonment. ${ }^{198}$ A year before Ford began publishing the National American, the anti-Catholic Bloody Monday riot, led by Know Nothing Party members, brought ethnic strife to Louisville, Kentucky, and unsettled the Catholic community of that city. Reflecting the popularity of Nativist sentiment in Kentucky in the early 1850s, Ford's publication replicated the violent and often mocking anti-Catholic rhetoric employed by George D. Prentice, the editor of Louisville's Know Nothing newspaper, the Journal. Prentice's famous "stinging wit," some historians argue, helped incite the riots that plagued Louisville in August 1855. ${ }^{199}$

Xenophobia remained a central theme throughout the life of Ford's publication, but the name of the paper changed several times as the editor addressed what he considered the most prominent threat to Protestant Americans. The publication's first title, National American, reflected Ford's embrace of American nationalism, free from the stain of any Catholic or foreign influence. The name also signified the editor's embrace of the Know Nothing or American Party's agenda. According to Michael Holt, the foremost historian of the Know Nothings, the party attracted "sincere zealots" who

\footnotetext{
${ }^{198}$ History of Daviess County, 197-98.

${ }^{199}$ Betty Carolyn Congleton, "George D. Prentice: Nineteenth Century Southern Editor," The Register of the Kentucky Historical Society 65 (April 1967): 105. On the Bloody Monday Riots, see George H. Yater, "Bloody Monday," in The Encyclopedia of Louisville, ed. John E. Kleber (Lexington: University of Kentucky Press, 2001), 97.
} 
responded "directly to sensational issues involving immigration and the Catholic Church. Most important, of course, was the influx of Catholic immigrants from famine-stricken Ireland and from Germany in the late 1840s." ${ }^{200}$ Ford later altered the publication's name several times to reflect the collapse of the Know Nothing Party in the late 1850s and the newspaper's shifting mission. Ford changed the name to The Shield to reflect the paper's goal of protecting the American way of life and the Protestant faith. Ford sought to "send out our Shield," believing that it would help "protect" the community "from harm.",201 During the Civil War, Ford changed the publication's name to Ford's Southern Shield. The inclusion of his own name in the title suggests Ford's rising political influence. ${ }^{202}$ Despite its changing name, Ford's core values remained intact. He dedicated his publication to combating foreign and Catholic influences in Daviess County and abroad and he continued to publish articles about the threat Catholic immigrants posed to American institutions, values, and character well into the 1870 s. $^{203}$

A stanch supporter of the southern cause, Ford's publication encountered a great deal of trouble during the Civil War when he came under the jurisdiction of Union General Jeremiah Tilford Boyle, who took command of Union forces in Kentucky on May 27, 1862. According to historian Ezra J. Warner, Boyle maintained a "civilian policy" that "alienated all but the most zealous Union sympathizers [in Kentucky], embracing as it did his ruthless punishments of persons suspected of "disloyalty." 204 As

\footnotetext{
${ }^{200}$ Michael Holt, cited in Mark E. Neely Jr., "Richard W. Thompson: The Persistent Know Nothing," Indiana Magazine of History 72 (June 1976): 96.

201 J. G. Ford, "Splinters," Ford's Southern Shield (Owensboro, KY), July 13, 1867.

202 "A Protest," Courier Journal, March 8, 1873. The article referred to Ford as a man "worthy of notice" and "too well known" "to the citizens of Owensboro." ${ }^{203}$ Ibid.

${ }^{204}$ Ezra J. Warner, Generals in Blue: Lives of Union Commanders (Baton Rouge:
} 
an influential and prolific Confederate sympathizer, Ford's editorial activities quickly caught the attention of the Union general. On June 10, 1862, fourteen days after Boyle's appointment, Union troops captured and arrested Ford and transported him to Louisville. Though Boyle soon released Ford, he had conveyed a clear message. Following his release, Ford relocated his publication south to Hartford, Kentucky, where he remained for over a year to avoid getting arrested again. ${ }^{205}$

Unfortunately, few issues of Ford's paper remain extant, though the two numbers that survive — from July 1867 and August 1873 —offer clear evidence of the xenophobic attitudes of many Daviess County residents. ${ }^{206}$ However, other newspapers reprinted many of the articles originally published in Ford's publication and regional outlets reported on his controversial political activities. Ford became adept at sensationalist journalism. Intelligent and well-spoken, Ford's writing found a ready local audience, in part because of his cutting wit. Much like George Prentice of the Louisville Journal, Ford regularly mocked immigrants and Catholics, utilizing a mean-spirited comedy to voice his aggressive political agenda. "Humorous antidotes" about immigrants, African Americans, and Catholics litter the pages of his newspaper. In August 1876, for example, the Louisville Courier-Journal reprinted an article from Ford's newspaper about the arrest of "Minnie Shamberger, colored, the great clairvoyant, astrologist and fortune teller" who had recently moved from New Orleans. Ford jested that "Minnie is a delicate

Louisiana State University Press, 1964), 40.

${ }^{205}$ History of Daviess County, 198.

206 The two issues of Ford's newspaper that remain extant are dated April 26, 1873 (held by the New York Historical Society) and July 13, 1867 (held by the Owensboro Museum of Science and History). 
little 300-pounder and has made quite a hubbub among the darkies since her arrival."207 Ford understood that mocking the behavior and customs of ethnic and racial outsiders appealed to his xenophobic audience and he skillfully included such "wit" throughout his reporting.

Ford's penchant for mocking and denigrating local immigrants appeared in full display in a controversy that made the pages of the Louisville Courier-Journal in 1873. An article published in Ford's Southern Shield outraged Owensboro's German community and prompted several of its prominent members to write in protest to the editor of the Louisville newspaper after he reprinted Ford's article. The article, entitled “A Protest: From German Citizens of Owensboro against a Series of Unfounded Aspersions," detailed the anger of the town's German community with both Ford's original article and his character. According to the protest, Ford's article attacked the German community for its alcohol consumption and recreation on the Sabbath. But the piece contained several errors about German culture that the outraged Germans sought to correct. "A more shameful and infamous article has never desecrated the columns of any paper than that on 'Sunday law' in Ford's Southern Shield of last issue" read the first line of the piece. The letter continued: "The article contains gross misinterpretations of German customs, and is an insult to every German man, woman and child, and we herewith brand it as the most malicious lie that has ever appeared in print." The protest revealed the contempt of the German community for both Ford and his paper. Ford attempted to turn native-born residents of Owensboro against German immigrants through accusations of indecency. Ford's article inaccurately claimed, for example, that

207 “Kentucky News,” Courier-Journal (Louisville), August 9, 1876. 
"marriages" in Germany were "on trial," meaning that German couples lived as man and wife in every way, including sexually, for twelve months before deciding whether they wished to commit to the marriage. "With what malicious delight does he not make bastards of a large part of the Germans, and with what devilish joy does he not drive all sympathizers from them by his bold accusations" fumed the authors of the protest. ${ }^{208}$ The German community understandably raged at Ford's accusations of fornication and adultery.

Ford's article also attacked the German community for its violations of "Sunday law," a regular feature of Nativist attacks on Catholic immigrants in the nineteenth century. Native-born Protestants took seriously their church's prohibitions against Sunday drinking and recreation and they viewed violations of these strictures as a sign of the immigrants' moral failings. Historians Steven Rowan and John Bodnar contend that cultural issues such as Sunday regulations and alcohol consumption were central concerns for Protestants who feared the influx of German and Irish immigrants. ${ }^{209}$ Protestants used Sunday closing laws, historian John Higham argued, as a means to prevent "the German conquest" of cities densely populated by German immigrants. ${ }^{210}$ German newcomers protested these laws. As historian Luke Ritter notes, "the Sunday issue continued to play a pivotal role in forming German Americans into an ethnic voting bloc." ${ }^{211}$ The more native-born Americans attacked Germans for their Sunday merriment,

\footnotetext{
208 "A Protest," Courier-Journal, March 8, 1873.

${ }^{209}$ See the introduction to Germans for a Free Missouri: Translations from the St. Louis Radical Press, 1857-1862, trans. by Steven Rowan, with introductions by James Neal Primm and Steven Rowan (Columbia: University of Missouri Press, 1983), 26. See also Bodnar, Transplanted, 197-98.

${ }^{210}$ Higham, Strangers, 25.

${ }^{211}$ Luke Ritter, "Sunday Regulation and the Formation of German American Identity,"
} 
the more tightly they clung to their cultural customs. The Sunday question arose as an issue in the earliest years of German and Irish Catholic migration to America and it continued for decades thereafter. As the German free-thinker Heinrich Börnstein noted in his Memoirs, “The beer question played a large role among German Americans, often too large a role." Several elections, he added, were "decided entirely on this issue."212

Ford understood the divisive nature of the Sunday question and he viewed his article as an effort to "drive all [German] sympathizers" out of the community. According to the 1870 U.S. Census, Daviess County produced 623,444 gallons of whiskey per year, more than thirty gallons of whiskey per person living in the county. ${ }^{213}$ The city of Owensboro alone had six large distilleries in operation. ${ }^{214}$ The economic importance of the local alcohol industry made it appear untouchable. Local publications ran articles pleading with drinkers to break free from the "filthy clutches of intemperance" that caused "damnation to their souls" and left "orphans whose fathers fill drunkards' graves." 215 But articles praising "Good Templars" and "delicate and modest women who undertook the temperance crusade" also ran alongside pieces describing the schematics of the newest completed distilleries. ${ }^{216}$ Loud and resolute local voices spoke out on behalf of

Missouri Historical Review 107 (October 2012): 3.

${ }^{212}$ Heinrich Börnstein, Memoirs of a Nobody: The Missouri Years of an Austrian Radical, 1849-1866, trans. and ed. by Steven Rowan (St. Louis: Missouri Historical Society Press, 1997), 198.

${ }^{213}$ An Illustrated Historical Atlas Map of Daviess County, Kentucky: Carefully Compiled from Personal Examinations and Surveys (Utica, KY: Leo McDonough and Co., 1876.), 13. For population statistics, see also United States Census Bureau, The Aggregate of all Censuses, "Population of each State and Territory by Counties" Table II, https://www2.census.gov/library/publications/decennial/1880/vol-01population/1880_v1-08.pdf (accessed May 7, 2018).

${ }^{214}$ History of Daviess County, 331.

215 The Owensboro Monitor, September 30, 1868.

216 The Owensboro Monitor, April 1, 1874. 
temperance but the wealth generated by the local alcohol industry often drowned them out. The economic impact of the distilling industry on Daviess County overshadowed the consequences of alcohol abuse. In this environment, Ford fabricated a new moral issue to besmirch the German community. When the question of alcohol consumption proved an ineffective weapon to attack the German community, Ford criticized the newcomers for their sexual immorality.

But Ford's plan backfired and even undermined his status in the community. His article did not turn the community against the Germans but instead sparked several influential figures to join a campaign against Ford and his publication. Outraged German leaders publicly denounced Ford's character and tactics in the Courier Journal. The protest noted that "it would be unwise to treat it with silent contempt because written by a man like J. G. Ford." Its authors argued that Ford's "prostituted sheet has been considerably spread abroad" and that the editor used it to dissuade "foreign capitalist and immigrants" from settling in the region. They believed it their duty to "guard the fair name of our city and neutralize the impression its local venom may make abroad."217 Owensboro's German community believed Ford a serpent who spat his venom into the pages of Ford's Southern Shield. In response, Ford claimed that the sentiments expressed in his newspapers were not his own but instead came from the very publication that offered the Germans of Owensboro a platform, the Courier Journal. The editor of the Louisville newspaper further discredited the Owensboro newspaperman by noting in print that Ford's claims "misrepresented" the Courier Journal because "the article never

217 “A Protest,” Courier Journal, March 8, 1873. 
appeared in these columns, either as editorial, communication or reprint." ${ }^{\text {218 }}$ The German community also rejected Ford's defense. "As for the Germans," their protest noted, "his attempts to reconcile them by the cheap assertion that the article was clipped from an exchange will be in vain. They have no use for a man of the character of J. G. Ford."219

The full effect of this debate on Ford's public reputation remains obscure because so few issues of his newspaper survive. But within two years of the article attacking German morality, Ford discontinued his newspaper and left Owensboro, relocating in Lacon, Illinois, and then in Baraboo, Wisconsin. There he continued as a newspaper editor and may have helped turn Sauk County from Republican to Democrat. ${ }^{220}$ In contrast, Ford's Owensboro publication had survived for seventeen years, including through the tumultuous events of the Civil War, but it foundered when he launched a scurrilous attack on Owensboro's growing German community, evidence of the rising influence of the newcomers.

The writings of Orr and Ford reveal that many of Owensboro's native-born Protestants perceived Catholic immigration as a threat. Anti-Catholicism and Nativism enjoyed broad support in the town and Daviess County for decades, beginning in the earliest years of settlement. Leading residents, politicians, preachers, and publishers openly and vehemently opposed the Catholic Church and the Catholic immigrants who brought that faith with them to the region. Nativist opposition proved fruitless in the end, however. Catholic, German, and Irish fraternal groups fostered the town's immigrant communities and cultures. The Catholic Church offered a sense of a community and

218 "Kentucky News," Courier Journal (Louisville), March 11, 1873.

219 "A Protest," Courier Journal, March 8, 1873.

${ }^{220}$ History of Daviess County, 198. 
political voice to many who otherwise lacked it. Catholic educational facilities nurtured the German language while also teaching devotion to the traditions of the church. Even before the 1880 publication of Orr's anti-Catholic and anti-immigrant screed, Owensboro's German community had mustered an influential political and economic presence in the community. Years after the book's publication, locals touted the town as a "place in Kentucky where Irish and Irish-Americans are loved and revered."221 Though Nativist sentiment did not disappear, by the turn of the twentieth century the Catholic and immigrant communities of Owensboro were firmly planted and attempts to lessen immigrant influence bound to fail.

221 “Representative Men,” Kentucky Irish American, June 29, 1901. 


\section{CONCLUSION}

In the late nineteenth century, the state of the Catholic community in Owensboro reflected the broader contours of American Catholicism. German, Irish, and native-born Catholics each reacted differently to the American experiment of multiculturalism. Owensboro and Daviess County also offer a clear picture of the growing pains of the American Catholic Church. ${ }^{222}$ The German and Irish communities, along with the church, crafted an American identity in these years. ${ }^{223}$ For centuries, each European nation developed distinctive Catholic practices. Catholic immigrants to the United States encountered cultures, divisions, and struggles unknown in their native home and in the process developed uniquely American practices. Though immigrant communities found solace in their faith, cultural differences undermined Catholic cohesion. German communities often refused to utilize the English language or permit non-Germans to worship with them. ${ }^{224}$ Native-born Catholics often allowed immigrants to worship with them, but only reluctantly and with limitations. ${ }^{225}$ And after 1900, divisions within the church only intensified as larger American cities received growing numbers of Italian and

${ }^{222}$ Andrew Arnold Lambing, A History of the Catholic Church in the Dioceses of Pittsburg and Allegheny from its Establishment to the Present Time (New York:

Benzinger Brothers, 1880), 221.

${ }^{223}$ Margaret Wilson Gillikin, "Competing Loyalties: Nationality, Church Governance, and the Development of an American Catholic Identity," Early American Studies 11 "Special Issue: Forming Nations, Reforming Empires: Atlantic Polities in the Long Eighteenth Century" (Winter 2013): 146.

${ }^{224}$ N. A. Weber, "The Rise of National Catholic Churches in the United States," The Catholic Historical Review 1 (January 1916): 428.

${ }^{225}$ Gillikin, “Competing Loyalties,” 147. 
Polish Catholics. ${ }^{226}$ The newcomers deepened the lines of division within the Catholic community and intensified nativist hostilities against Catholicism.

At the Third Plenary Council of Baltimore, which took place in 1884, the church leadership codified its outreach to immigrant communities, ensuring that such practices would continue. Catholic immigrants insisted on preserving their ethnic communities, and many clergy supported the practice. ${ }^{227}$ The council divided over controversial topics like modernism, but attendees concurred that the church would continue to serve each immigrant group in their own language and tradition. ${ }^{228}$ Indeed, the church hierarchy appeared delighted by the unique situation of Catholicism in the United States. Pope Leo XIII remarked, "We highly esteem and love exceedingly the young and vigorous American nation," adding, "we behold the Church, from scant and slender beginnings, grown to rapidity to be great and exceedingly flourishing." 229 The leaders who attended the council viewed the continued growth and success of the Catholic Church as paramount. They thus embraced "Title viii, Of Zeal of Souls," continuing the practice of national parishes — that is, parishes established for immigrants — and making it standard practice for the Catholic Church to continue to preach to immigrants in their native tongue. The decision ensured Catholic immigrants' ongoing support for the church within

226 Jacobson, Whiteness, 43, 69.

227 Jay P. Dolan, "Immigrants in the City: New York's Irish and German Catholics," Church History 41 (September 1972): 360-61.

${ }^{228}$ Anthony D. Andreassi, “"The Cunning Leader of a Dangerous Clique'?: The Burtsell Affair and Archbishop Michael Augustine Corrigan," The Catholic Historical Review 86 (October 2000): 624.

${ }^{229}$ Leo XIII, “LONGINQUA,” http://w2.vatican.va/content/leoxiii/en/encyclicals/documents/hf_l-xiii_enc_06011895_longinqua.html (accessed November 19, 2019). 
the United States. ${ }^{230}$

With Catholic influence under attack throughout Europe in the nineteenth century, the Holy See happily accepted the decision of the Third Plenary Council. Throughout the century, a succession of popes had battled the ideologies of liberalism and modernism, both spiritually and materially. After the Napoleonic Wars, the growth of liberalism continued to be a primary concern of the Catholic leadership. ${ }^{231}$ The conflict culminated in Pius IX's exile to Rome. The pope had battled Italian nationalists for years, but in 1870 they annexed the Papal States and established the unified kingdom of Italy. The Catholic leadership feared the growth of liberalism in Italy as well as in Germany under the chancellorship of Otto von Bismarck. Consequently, church leaders endeavored to maintain the influence and tradition of Catholicism wherever possible.

In this context, the leadership of the Catholic Church in America worked to cater to the desires of the laity. Though the creation of national perishes made it difficult to maintain a cohesive American church, they enabled Catholicism to flourish. As one scholar who lived through the formation of national perishes marveled, "in spite of the numerous and frequently antagonistic nationalities which emigration has thrown on our shores, the Catholic Church stands today in the United States no less united than it is in any country in the world." ${ }^{232}$ In its global reach, the Catholic Church had always constituted a diverse amalgamation of peoples. The situation in the United States

\footnotetext{
${ }^{230}$ Newadvent.org, "Plenary Councils of Baltimore," http://www.newadvent.org/cathen/02235a.htm (accessed May 18, 2018).

${ }^{231}$ Alan J. Reinerman, “An Unnatural 'Natural Alliance': Metternich, Palmerston, and the Reform of the Papal States, 1831-1832," The International History Review 10 (November 1988): 541-43.

${ }^{232}$ Weber, "The Rise of National Catholic Churches," 422.
} 
impelled church leaders to implement a similar structure on a smaller scale. The cultural divisions of Daviess County thus reflected broader national trends. As in Owensboro and Daviess County, the Catholic Church represented a diverse collection of ethnic communities. While nativists and others opposed all Catholics, the church retained its internal divisions. Indeed, the divisions and struggles that faced the American Catholic Church in this era also defined it. The work of priests like Fathers Volk and Gambon among their fellow immigrants enabled the church to grow, while its diversity ensured that it possessed a decidedly American quality 


\section{REFERENCES}

\section{Manuscript Sources}

Bouchet, Michael to Reverend Peter Haeseley, November 13, 1878. Diocese of Owensboro Online Archive, 2017.https://owensboro.pastperfectonline.com/archive/412F149C-9982-4938A757-574886516859. (Accessed July 10, 2017).

Bouchet, Michael to Reverend Peter Haeseley, May 3, 1879. Diocese of Owensboro Online Archive, 2018. https://owensboro.pastperfectonline.com/archive/DE75DEFC-6A64-462D-80F2459810950538. (Accessed July 10, 2017)

Bouchet, Michael to Reverend Peter Haeseley, May 7, 1879. Diocese of Owensboro Online Archive, 2018. https://owensboro.pastperfectonline.com/archive/F0312981-46FA-448F-A167043243473260. (Accessed July 10, 2017).

Bouchet, Michael Bouchet to Reverend Peter Haeseley, Dec 18, 1879, Diocese of Owensboro Online Archive. https://owensboro.pastperfectonline.com/archive/E7580538-502D-4F9C-8748599320448323. (Accessed July 10, 2017).

"Brief History of St. Joseph's Parish, Owensboro, Ky." The Record (Louisville), April 7, 1938.

Father Gambon Interview (Louisville, KY), December 13, 1897. St. Paul Collection, Diocese of Owensboro Archives, Owensboro, KY.

"Father Volk Organized St. Joseph's, Owensboro." St. Paul Collection, Diocese of Owensboro Archives, Owensboro, KY.

Leo XIII. “LONGINQUA.” http://w2.vatican.va/content/leoxiii/en/encyclicals/documents/hf_1-xiii_enc_06011895_longinqua.html. Accessed November 19, 2019.

McCloskey, William to Reverend Peter Haeseley, October 30, 1879. Diocese of Owensboro Online Archive. 
https://owensboro.pastperfectonline.com/archive/18660BE6-BDD5-4CC4-A1A0$\underline{024100444966}$. (Accessed July 10, 2017).

McCloskey, William to Reverend Peter Haeseley, November 27, 1879. Diocese of Owensboro Online Archive. https://owensboro.pastperfectonline.com/archive/441B5BF1-A2C4-4EEB-9138510592807936. (Accessed July 10 2017).

McCloskey, William to Thomas Gambon. December 4, 1886. Louisville, Kentucky. St. Paul Collection, Diocese of Owensboro Archives, Owensboro, Kentucky.

Moody, Granville. A Life's Retrospect: Autobiography of Reverend Granville Moody D. D. (Brigadier General by Brevet). Ed. Reverend Silvester Weeks. New York: Hunt and Eaton, 1890.

Oberst, Mary Tennes. “Father Volk Organized St. Joseph’s, Owensboro”, St. Joseph Collection, Mount St. Joseph Archives, Maple Mount, Kentucky.

—_. "Origin of St. Joseph's Church, Owensboro, Kentucky." St. Joseph School, Mount Saint Joseph Archives, Maple Mount, Kentucky.

—_ "Dedication of St. Alphonsus' Church, May 14 or 16, 1871." St. Joseph School, Mount Saint Joseph Archives, Maple Mount, Kentucky.

Official Service and Instruction Bookfor St. Paul's Parish of Owensboro, Ky. 1905-1910. Owensboro, KY: Payne Printing Company, 1905. St. Paul Collection, Diocese of Owensboro, Owensboro, Kentucky.

Spiess, Eugene. "Brief History of St. Josephs Parish.” St. Joseph Collection, Mount St. Joseph Archives, Maple Mount, Kentucky.

United States Census, 1880. Family Search. https://www.familysearch.org/ark:/61903/3:1:33S7-9YBX93CV? $\mathrm{i}=22 \& \mathrm{cc}=1417683$. Accessed October 15, 2017.

United States Census Bureau. The Aggregate of all Censuses. "Population of each State and Territory by Counties," Table II. https://www2.census.gov/library/publications/decennial/1880/vol-01population/1880_v1-08.pdf. Accessed May 7, 2018.

United States Census Bureau. 1850 Kentucky Census of Daviess, Edmondson, and Estill. Washington: National Archives Microfilm Publications, 1963. 
United States Census Bureau. 1900 Kentucky Federal Population Census Schedules: Crittenden, Cumberland, and Daviess Counties, Reel 517. Washington: National Archives Microfilm Publications, 1978.

Printed Primary Sources

Amy's Probation; or, Six Months at a Convent: An Answer to the Question, Shall Protestant Girls be sent to Roman Catholic Schools? New York: Phillips and Hunt, 1880.

An Illustrated Historical Atlas Map of Daviess County, KY: Carefully Compiled from

Personal Examinations and Surveys. Utica, KY: Leo McDonough and Co., 1876.

Börnstein, Heinrich. Memoirs of a Nobody: The Missouri Years of an Austrian Radical, 1849-1866. Trans. and ed. Steven Rowan. St. Louis: Missouri Historical Society Press, 1997.

Crawford, Martin, ed. William Howard Russell's Civil War: Private Diary and Letters, 1861-1862. Athens: University of Georgia Press, 1992.

Orr, Benjamin Franklin. The Papal Power in Politics, or Rome against Liberty. Owensboro, KY: n.p. 1881.

Rowan, Steven, trans. Germans for a Free Missouri: Translations from the St. Louis Radical Press, 1857-1862. Columbia: University of Missouri Press, 1983.

Strong, Josiah. Our Country: Our Possible Future and Our Present Crisis. New York: Baker and Taylor, 1885.

Thompson, R. W. The Papacy and the Civil Power. New York: Harper and Brothers, 1876.

Van Evrie, John H. Negroes and Negro "Slavery": The First an Inferior Race; the Latter Its Normal Condition. New York: Van Evrie, Horton, and Co., 1861.

\section{Newspapers}

"A Branch of the Irish Land League Organized." Courier-Journal (Louisville), May 12, 1881.

“A Murder.” Kentucky Irish American (Louisville), August 9, 1901. 
"A Protest: From German Citizens of Owensboro against a Series of Unfounded Aspersions." Courier-Journal (Louisville), March 8, 1873.

“An Irish Wake.” Courier-Journal (Louisville), February 20, 1880.

“Devoted but Drunk.” Courier-Journal (Louisville), July 3, 1889.

"Father Gambon a Monsignor." Courier-Journal (Louisville), January 3, 1897.

Ford, J. G. "Splinters.” Ford's Southern Shield (Owensboro, KY), July 13, 1867.

“Horrible Consequence of Intemperance.” Louisville Daily Journal, March 21, 1837.

“Kentucky News.” Courier-Journal (Louisville), August 9, 1876.

Nast, Thomas. “The Ignorant Vote-Honors are Easy.” Harper's Weekly, December 9, 1876.

"Owensboro: Representative Men of Irish Decent in Every Business and Industry Acquit Themselves with Credit.” Kentucky Irish American (Louisville), June 29, 1901.

“The Churches.” Courier-Journal (Louisville), October 18, 1896.

“The Irish Wake: It Is a Kindly and Humane Custom In Intention.” Courier-Journal (Louisville), October 18, 1898.

"The Order of Harugari: It Was Founded in New-York on German Mythology. Started for Defense - Perpetuated for Charity. Its Lodges Are Found in Nearly All the States, and Its Benefits Have Been Felt Throughout the Land-A Sketch of the Order." New York Times, August 25, 1895.

Secondary Sources

Allen, William B. A History of Kentucky: Embracing Gleanings, Reminiscences, Antiquities, Natural Curiosities, Statistics, and Biographical Sketches of Pioneers, Soldiers, Jurists, Lawyers, Statesmen, Divines, Mechanics, Farmers, Merchants, and Other Leading Men, of All Occupations and Pursuits. Louisville: Bradley and Gilbert, 1872.

Andreassi, Anthony D. “"The Cunning Leader of a Dangerous Clique'? The Burtsell Affair and Archbishop Michael Augustine Corrigan." The Catholic Historical Review 86 (October 2000): 620-39. 
Barkan, Elliot R., Rudolph J. Vecoli, Richard D. Alba and Olivier Zunz. "Race, Religion, and Nationality in American Society: A Model of Ethnicity: From Contact to Assimilation.” Journal of American Ethnic History 14 (Winter 1995): 285-301.

Billington, Ray Allen. "Maria Monk and Her Influence." The Catholic Historical Review 22 (October 1936): 283-96.

Bodnar, John. The Transplanted: A History of Immigrants in Urban America. Bloomington: University of Indiana Press, 1985.

Castillo, Dennis. "The Enduring Legacy of Maria Monk." American Catholic Studies 112 (Spring-Winter 2001): 49-59.

Cave, Alfred A. The French and Indian War. Westport, CT: Greenwood Publishing Group, 2004.

Colburn, Ronald. "A History of Graves County" in "The Catholic Settlement": A History of St. Jerome Catholic Church, 1836-2011. Ed. Cynthia Pierce Elder. Morrisville, NC: Lulu Press, 2012.

Congleton, Betty Carolyn. "George D. Prentice: Nineteenth Century Southern Editor." The Register of the Kentucky Historical Society 65 (April 1967): 94-119.

Conzen, Kathleen Neils. Immigrant Milwaukee, 1836-1860: Accommodation and Community in a Frontier City. Cambridge, MA: Harvard University Press, 1976.

_. "Immigrant Religion and the Public Sphere: The German Catholic Milieu in America." In German-American Immigration and Ethnicity in Comparative Perspective. Ed. Wolfgang J. Helbich, 69-117. Madison, WI: Max Kade Institute for German-American Studies, 2005.

Cossen, William S. "Monk in the Middle: The "Awful Disclosures of the Hotel Dieu Nunnery' and the Making of Catholic Identity." American Catholic Studies 125 (Spring 2014): 25-45.

Dew, Lee A. "Our People: A Burgoo Pot of Cultures." In Daviess County, Kentucky 1815-2015: Celebrating Our Heritage, 19-25. Evansville, IN: M. T. Publishing Company, 2015.

and Aloma W. Dew. Owensboro: The City on the Yellow Banks. Bowling Green, KY: Rivendell Publications, 1990.

Dolan, Jay P. "Immigrants in the City: New York's Irish and German Catholics." Church History 41 (September 1972): 354-68. 
—_ "The Irish Parish.” U.S. Catholic Historian 25 (Spring 2007): 13-24.

Dorries, Reinhard R. "Immigrants and the Church: German-Americans in Comparative Perspective." In German-American Immigration and Ethnicity in Comparative Perspective.Ed. Wolfgang J. Helbich, 3-18. Madison, WI: Max Kade Institute for German-American Studies, 2005.

Dyer, Thomas G. Roosevelt and the Idea of Race. Baton Rouge: Louisiana State University Press, 1992.

Gillikin, Margaret Wilson. "Competing Loyalties: Nationality, Church Governance, and the Development of an American Catholic Identity." Early American Studies 11 Special Issue: Forming Nations, Reforming Empires: Atlantic Polities in the Long Eighteenth Century (Winter 2013): 146-160.

Gleeson, David T. The Green and the Gray: The Irish in the Confederate States of America. Chapel Hill: University of North Carolina Press, 2013.

- The Irish in the South, 1815-1877. Chapel Hill: University of North Carolina Press, 2001.

Graves County, Kentucky, History and Families. Paducah, KY: Turner Publishing Company, 2001.

Green, James J. "American Catholics and the Irish Land League, 1879-1882." The Catholic Historical Review 35 (April 1949): 19-42.

Haden, Kyle E. "Anti-Catholicism in U.S. History: A Proposal for a New Methodology." American Catholic Studies 124 (Winter 2013): 27-45.

Handlin, Oscar. Boston's Immigrants 1790-1880: A Study of Acculturation. 1959; Cambridge, MA: The Belknap Press of Harvard University Press, 1991.

- The Uprooted, the Epic Story of the Great Migrations that Made the American People. Boston: Little, Brown, 1952.

Hatfield, Douglas W. "Kulturkampf: The Relationship of Church and State and the Failure of German Political Reform." Journal of Church and State 23 (Autumn 1981), 465-84.

Hawgood, John A. The Tragedy of the German American: The Germans in the United States of America during the Nineteenth Century - and After. New York: G. P. Putnam's Sons, 1940. 
Higham, John. Strangers in the Land: Patterns of American Nativism, 1860-1925. New Brunswick, NJ: Rutgers University Press, 1988.

Hiort, Pontus. "Constructing Another Kind of German: Catholic Commemorations of German Unification Baden, 1870-1876." The Catholic Historical Review 93 (January 2007): 17-46.

History of Daviess County, Kentucky, Together with Sketches of its Cities, Villages and Townships, Educational, Religious, Civil, Military, and Political History; Portraits of Prominent Persons, Biographies of Representative Citizens, and an Outline History of Kentucky. Chicago: Interstate Publishing, 1883.

History of Warrick, Spencer, and Perry Counties, Indiana: From the Earliest Time to the Present; Together with Interesting Biographical Sketches Reminisces, Notes, Etc. Chicago: Goodspeed Bros., 1885.

Ignatiev, Noel. How the Irish became White. New York: Routledge, 1995.

Ireland, John. "The Catholic Church and the Saloon," The North American Review 159 (October 1894): 498-505.

Jacobson, Matthew Frye. Whiteness of a Different Color: European Immigrants and the Alchemy of Race. Cambridge, MA: Harvard University Press, 1998.

Knobel, Dale T. "To Be an American: Ethnicity, Fraternity, and the Improved Order of Red Men." Journal of American Ethnic History 4 (Fall 1984): 62-87.

"Kundek Corner: Ferdinand Distinguished Citizens, Father Joseph Kundek," Ferdinand Historical Society. http://www.ferdinandhistory.org/index.php/kundek-corner/frjoseph-kundek. Accessed September 3, 2018.

Lallou, William J. "Catholic Loyalty to America." Records of the American Catholic Historical Society of Philadelphia 62 (September 1951): 181-83.

Lambing, Andrew Arnold. A History of the Catholic Church in the Dioceses of Pittsburg and Allegheny from Its Establishment to the Present Time. New York: Benzinger Brothers, 1880.

Laski, Harold Joseph. Studies in the Problem of Sovereignty. New Haven, CT: Yale University Press, 1917.

Maes, Camilles P. The Life of Rev Charles Nerinckx: With a Chapter on the Early Catholic Missions of Kentucky; Copious Notes on the Progress of Catholicity in the United States of America, from 1800 to 1825; An Account of the Establishment of the Society of Jesus in Missouri; And an Historical Sketch of the 
Sisterhood of Loretto in Kentucky, Missouri, New Mexico, Etc. Cincinnati: R. Clarke and Co, 1880.

Matovina, Timothy M. "The National Parish and Americanization," U.S. Catholic Historian 17 "Americanism and Americanization: Essays in Honor of Philip Gleason" (Winter 1999): 45-58.

Mattingly, Mary Ramona. The Catholic Church on the Kentucky Frontier, 1785-1812. Washington D.C.: Catholic University of America, 1936.

McCaffrey, Lawrence John. "Irish Textures in American Catholicism." The Catholic Historical Review 78 (January 1992): 1-18.

—. The Irish Catholic Diaspora in America. Washington, D.C.: Catholic University of America Press, 1997.

McGill, Anna Blanche. The Sisters of Charity of Nazareth, Kentucky. New York: Encyclopedia Press, 1917.

McMahon, Cian T. "Caricaturing Race and Nation in Irish American Press, 1870-1880: A Transnational Perspective." Journal of Ethnic History 33 (Winter 2014): 33-56.

Miller, Kirby A. Emigrants and Exiles Ireland and the Irish Exodus to North America. New York: Oxford University Press, 1985.

Moloney, Deirdre M. "Land League Activism in Transnational Perspective." U.S. Catholic Historian 22 "Ireland and America: Religion, Politics, and Social Movements" (Summer 2004): 61-74.

Moss, Kenneth. "St. Patrick's Day Celebrations and the Formation of Irish-American Identity, 1845-1875." Journal of Social History 29 (Autumn 1995): 125-48

Neely Jr., Mark E. "Richard W. Thompson: The Persistent Know Nothing.” Indiana Magazine of History 72 (June 1976): 95-122.

Patterson, Sarah. "The Catholic Church in Daviess County," in Daviess County Kentucky, 1815-2015: Celebrating Our Heritage, 133-45. Evansville, IN: M. T. Publishing, 2015.

Pitts, Reginald H. “'Suckers, Soap-Locks, Irishmen and Plug-Uglies': Block 160, Municipal Politics and Local Control." Historical Archaeology 35, no. 3, Becoming New York: The Five Points Neighborhood (2001): 89-102. 
Reinerman, Alan J. “An Unnatural 'Natural Alliance': Metternich, Palmerston, and the Reform of the Papal States, 1831-1832." The International History Review 10 (November 1988): 541-58.

Rippley, LaVern J. "The Ethnic Frontier: Rural Germans and the Settlement of America," in Immigrant America: European Ethnicity in the United States. Ed. Timothy Walsh, 197-215. New York: Routledge, 1994.

Ritter, Luke. "Sunday Regulation and the Formation of German American Identity." Missouri Historical Review 107 (October 2012): 23-40.

Rothensteiner, John. "Paul de Saint Pierre: The First German-American Priest of the West." The Catholic Historical Review 5 (July-October 1919): 195-222.

Russ Jr., William A. “Anti-Catholic Agitation during Reconstruction.” Records of the American Catholic Historical Society of Philadelphia 45 (December 1934): 31221.

Russwurm, Norbert. Rev. Paul Joseph Volk: A Pioneer Missionary in Two Continents. St. Bernard, AL: St. Bernard Abbey Book Shop, 1937.

Schrag, Peter. Not Fit for Our Society: Nativism and Immigration. Berkley: University of California Press, 2010.

Sewrey, Charles L. "Infallibility, the American Way, and Catholic Apologetics." Journal of Church and State 15 (Spring 1973): 293-302.

Spalding, Thomas W. "The Maryland Catholic Diaspora." U.S. Catholic Historian 8 (Summer 1989): 162-72.

Stefaniuk, Thomas. "Joseph Jessing, German-American Catholics, and National MythMaking in Late Nineteenth-Century America." American Catholic Studies 126 (Spring 2015): 1-24.

The Roman Catholic Diocese of Owensboro, Kentucky. Nashville, TN: Turner Publishing Company, 1994.

Trachtenberg, Alan. The Incorporation of America: Culture and Society in the Gilded Age. New York: Hill and Wang, 1997.

Ullrich, C. Robert, Jane K. Keller, and Joseph R. Reinhart, "Germans," in The Encyclopedia of Louisville. Ed. John E. Kleber, 338-39. Lexington: University of Kentucky Press, 2001. 
Warner, Ezra J. Generals in Blue: Lives of Union Commanders. Baton Rouge: Louisiana State University Press, 1964.

Webb, Benedict Joseph. The Centenary of Catholicity in Kentucky. Louisville: C. A. Rodgers, 1884.

Weber, N. A. "The Rise of National Catholic Churches in the United States." The Catholic Historical Review 1 (January 1916): 422-434.

Weisert, John J. “Lemcke Visits Kentucky's German Colonies in 1885.” The Register of the Kentucky Historical Society 75 (July 1977): 222-232.

Wilkerson, Gerald M. That All May Be One: A History of Sts. Joseph and Paul Parish on Centenary Celebration of Saint Paul's Church, 1887-1987. Utica, KY: McDowell Publishing, 1987.

Yater, George H. "Bloody Monday," in The Encyclopedia of Louisville. Ed. John E. Kleber, 97. Lexington: University of Kentucky Press, 2001.

Yox, Andrew P. “Bonds of Community: Buffalo’s German Element, 1853-1871.” New York History 66 (April 1985): 140-63. 


\section{CURRICULUM VITA}

NAME:

ADDRESS:

DOB:

EDUCATION: $\quad$ M.A., History

University of Louisville

2015-2019

B.A., History

Eastern Kentucky University

2012-2014

AWARDS: $\quad$ 2012- Office of the Dean, EKU - Fall 2012 Dean's List

2013-Office of the President, EKU - Spring 2013 President's List

2013- Office of the Dean, EKU - Spring 2013 Dean's List

2013-Office of the President, EKU - Fall 2013 President's List

2013-Office of the Dean, EKU - Fall 2013 Dean's List

2014-Best Undergraduate paper- $3^{\text {rd }}$ place Phi Alpha Theta

Regional Conference

2015-Ryant Memorial Awards for Graduate Students

CONFERENCE PRESENTATIONS: 
“'Steel and a Strong Attitude': Theodore Roosevelt and Kaiser Wilhelm II's Transnational Arms Race" Award Winning Paper, Phi Alpha Theta Conference, Richmond, KY, October 2014

\section{PUBLIC HISTORY EXPERIENCE:}

2016-Historic Preservation Agent, Louisville Metro Development, Internship, Louisville, KY

2017-Fiscal Court Digital Archival Leadership, Owensboro Fiscal Court, Internship, Owensboro, KY

2017-Museum Archival Assistant, Owensboro Museum of Science and History, Intern, Owensboro, KY 